\title{
Chemical composition of 8 eucalyptus species' essential oils and the evaluation of their antibacterial, antifungal and antiviral activities
}

Ameur Elaissi $^{1 *}$, Zyed Rouis ${ }^{2}$, Nabil Abid Ben Salem², Samia Mabrouk ${ }^{5}$, Youssef ben Salem ${ }^{3}$, Karima Bel Haj Salah², Mahjoub Aouni ${ }^{2}$, Farhat Farhat ${ }^{4}$, Rachid Chemli ${ }^{1}$, Fethia Harzallah-Skhiri ${ }^{5}$ and Mohamed Larbi Khouja ${ }^{6}$

\begin{abstract}
Background: In 1957, Tunisia introduced 117 species of Eucalyptus; they have been used as fire wood, for the production of mine wood and to fight erosion. Actually, Eucalyptus essential oil is traditionally used to treat respiratory tract disorders such as pharyngitis, bronchitis, and sinusitis. A few investigations were reported on the biological activities of Eucalyptus oils worldwide. In Tunisia, our previous works conducted in 2010 and 2011 had been the first reports to study the antibacterial activities against reference strains. At that time it was not possible to evaluate their antimicrobial activities against clinical bacterial strains and other pathogens such as virus and fungi.

Methods: The essential oils of eight Eucalyptus species harvested from the Jbel Abderrahman, Korbous (North East Tunisia) and Souinet arboreta (North of Tunisia) were evaluated for their antimicrobial activities by disc diffusion and microbroth dilution methods against seven bacterial isolates: Haemophilus influenzae, Klebsiella pneumoniae,

Pseudomonas aeruginosa, Staphylococcus aureus, Streptococcus agalactiae, Streptococcus pneumoniae and

Streptococcus pyogenes. In addition, the bactericidal, fungicidal and the antiviral activities of the tested oils were carried out.
\end{abstract}

Results: Twenty five components were identified by GC/FID and GC/MS. These components were used to correlate with the biological activities of the tested oils. The chemical principal component analysis identified three groups, each of them constituted a chemotype. According to the values of zone diameter and percentage of the inhibition (zdi, \% I, respectively), four groups and subgroups of bacterial strains and three groups of fungal strains were characterized by their sensitivity levels to Eucalyptus oils. The cytotoxic effect and the antiviral activity varied significantly within Eucalyptus species oils.

Conclusions: E. odorata showed the strongest activity against S. aureus, H. influenzae, S. agalactiae, S. pyogenes, S. pneumoniae and against all the tested fungal strains. In addition, E. odorata oil showed the most cytotoxic effect. However, the best antiviral activity appeared with E. bicostata. Virus pretreatment with E. bicostata essential oil showed better antiviral activity $\left(I C_{50}=0.7 \mathrm{mg} / \mathrm{ml}, \mathrm{SI}=22.8\right)$ than cell-pretreatment $\left(I C_{50}=4.8 \mathrm{mg} / \mathrm{ml}, \mathrm{SI}=3.33\right)$. The essential oil of $E$. astringens showed antiviral activity only when incubated with virus prior to cell infection. This activity was dose-dependent and the antiviral activity diminished with the decreasing essential oil concentration.

Keywords: Eucalyptus sp., Essential oil, Principal Components Analysis, Hierarchical Cluster Analysis, Antibacterial activity, Antifungal activity, Antiviral activity

\footnotetext{
* Correspondence: aelaissi@yahoo.fr

'Laboratory of Pharmacognosy, Faculty of Pharmacy, University of Monastir, Avenue Avicenne, Monastir 5019, Tunisia

Full list of author information is available at the end of the article
}

\section{() Biomed Central}

(c) 2012 Elaissi et al.; licensee BioMed Central Ltd. This is an Open Access article distributed under the terms of the Creative Commons Attribution License (http://creativecommons.org/licenses/by/2.0), which permits unrestricted use, distribution, and reproduction in any medium, provided the original work is properly cited. 


\section{Background}

The Eucalyptus, a native genus from Australia, belongs to Myrtaceae family and comprises about 900 species [1]. More than 300 species of this genus contain volatile oils in their leaves. Fewer than 20, within these species, known for their high content of 1,8-cineole (more than $70 \%$ ), have been commercially used for the production of essential oils in pharmaceutical and cosmetic industries [2]. Over the past few years, the interest in natural medicine has been increasing in industrialized societies particularly against microbial agents because of the ever growing problem of antibiotic resistance [3]. In Tunisian folk medicine, inhalation of Eucalyptus sp. essential oil has traditionally been used to treat respiratory tract disorders such as pharyngitis, bronchitis, and sinusitis [4]. Consequently, the scientific interest in this field has been expanding. Some researchers have demonstrated some efficacy of Eucalyptus globulus essential oil against Haemophilus influenzae and Stenotrophomonas maltophilla [3,5]. Streptococcus pyogenes, Streptococcus pneumoniae, Streptococcus agalctia, Staphylococcus aureus, Pseudomonas aeruginosa, Klebsiella pneumonia and Hemophilis influenzae are the most important causes of the respiratory tract infections and the most resistant to antibiotics. Many studies reported the antifungal propriety of plant extracts and essential oils against dermatophytes, filamentous and Candida albicans [6,7]. The essential oils extracted from Eucalyptus species, mainly from E. urophylla S.T. Blake, E. grandis, E. camaldulensis, E. citriodora and E. globulus were found to be active on phyto-pathogenic fungi [8-10].

Few studies have reported the antiviral activity of Eucalyptus essential oils against Adenovirus, mumps and herpes simplex viruses $[11,12]$. One of the major challenges is the practical use of these essential oils in vivo. This is difficult and needs to be overcome by trial assays. The importance of the antiviral activity of natural compounds is their perspective uses against these pathogens. Enteroviruses are more prevalent in the environment than the viruses discussed above and it is worth studying them for any antiviral activity. To the best of our knowledge, there is no published report on the Eucalyptus essential oils' activities against human fungal and enteroviral infections. As reported previously $[13,14]$, we have studied the antibacterial activity of 35 Eucalyptus essential oils against four reference gastrointestinal strains (Esherichia coli, ATCC 25922; Pseudomonas aeruginosa, ATCC 227853; Enterococcus faecalis, ATCC 292112; Staphylococcus aureus, ATCC 25932) using the disc diffusion method. On the basis of the best diameter inhibition against these pathogens, eight Eucalyptus essential oils were selected and used to evaluate their activity against bacterial strains isolated from patients suffering respiratory infections. In addition, these oils were tested for their antifungal and anti-enteroviral activities.

\section{Methods}

\section{Plant materials}

Samples of clean mature leaves of eight species of the genus Eucalyptus L'HÉR., five of which were collected in June 2006 from Souiniat arboreta located in the North west of Tunisia (E. bicostata, E. cinerea, E. maidenii, E. odorata and E. sideroxylon); two species were collected in April 2006 from Korbous arboreta (E. astringens and E. lahmannii); one species was collected from Jbel abderrahaman arboreta (E. leucoxylon). The last two arboreta were located in Nabeul region (North East of Tunisia with sub-humid bioclimatic stage). Botanical voucher specimens have been deposited in the Pharmacognosy Laboratory Herbarium in the Faculty of Pharmacy (Monastir, Tunisia), under the following references: 0119, 0120, 0126, 0127, 0129, 0132, 0138 and 0154 .

\section{Extraction of essential oils}

The extraction of essential oils was carried out by hydrodistillation during four hours, using a standard apparatus recommended in the European Pharmacopoeia. We made three attempts for each sample of $100 \mathrm{~g}$ of boorishly crushed dried leaves for each species. The oil collected from each plant was then dehydrated with $\mathrm{Na}_{2} \mathrm{SO}_{4}$ (Sigma-Aldrich, NY, USA) and stored at $4^{\circ} \mathrm{C}$ until use.

\section{Chemical analysis}

Quantitative and qualitative data for all the essential oils were performed in triplicate by Gaz Chromatography (GC) and Gaz Chromatography coupled with the Mass Spectroscopy (GC/MS), respectively.

\section{Gas chromatography analysis}

GC was carried out using Hewlett-Packard (HP) 6890 chromatography apparatus equipped with Flame Ionization Detector (FID) and Carbowax column (30 m x $0.32 \mathrm{~mm}$ i.d., film thickness $0.25 \mu \mathrm{m}$ ) under the following analytical conditions: injector and detector temperatures were maintained at $250^{\circ} \mathrm{C}$ and $280^{\circ} \mathrm{C}$, respectively; oven temperature programmed to rise from $35^{\circ} \mathrm{C}$ to $250^{\circ} \mathrm{C}$ at $5^{\circ} \mathrm{C} / \mathrm{min}$, isothermal temperature $35^{\circ} \mathrm{C}$ for $1 \mathrm{~min}$ and $250^{\circ} \mathrm{C}$ for $3 \mathrm{~min}$; the carrier gas was nitrogen with a flow rate of $1.2 \mathrm{~mL} / \mathrm{min}$., the injected volume was $1 \mu \mathrm{L}$ sample of $10 \%$ solution of oil in purified hexane. Relative concentrations were calculated using the software HP Chemstation, which allows the assimilation of the percentages of the peak areas to the percentages of the various constituents. Retention indices were obtained by running a series of aliphatic hydrocarbons (C9 - C28) by 
increasing the number of carbon atoms in the Carbowax GC column).

\section{Gas chromatography-mass-spectrometry analysis}

The chemical analysis of the essential oils was carried out using a HP 5890 series II gas chromatography apparatus equipped with a polar column Carbowax (30 m x $0.32 \mathrm{~mm}$ i.d., film thickness $0.25 \mu \mathrm{m}$ ) and 5972 mass selective detectors. Helium was used as the carrier gas. The mass spectrometer operating conditions were: ionisation voltage, $70 \mathrm{eV}$, ion source $230^{\circ} \mathrm{C}$. The GC/MS parameters were identical to those for the $\mathrm{GC}$ analysis.

\section{Compound identification}

The identification of the compounds was based on the comparison of their retention index (determined relatively to the retention time of aliphatic hydrocarbons (C9 - C28) and of the mass spectra with those of authentic compounds by means of NBS75K.L. and Wiley 275 databases and with the literature data) [15].

\section{Antibacterial testing}

\section{Bacterial strains}

The bacterial strains used in the present study were seven clinical bacterial isolates: Haemophilus influenzae (11 strains), Klebsiella pneumoniae (13 strains), Pseudomonas aeruginosa (10 strains), Staphylococcus aureus (17 strains), Streptococcus agalactiae (9 strains), Streptococcus pneumoniae (19 strains) and Streptococcus pyogenes (2 strains). These clinical strains were obtained from Microbiology and Immunology Laboratory (EPS Farhat Hachad, Sousse, Tunisia).

\section{Kirby Bauer paper method}

The antibacterial activity of the different essential oils was evaluated by the paper-disc agar diffusion method with a bacterial inoculum of 0.5 Mcfarland; MuellerHinton (MH) with 5\% sheep blood or with $\mathrm{MH}$ only for Pseudomonas aeruginosa, and Staphylococcus aureus. Absorbent discs (Whatman disc $\mathrm{n}^{\circ} 3,6 \mathrm{~mm}$ diameter) were impregnated with $10 \mu \mathrm{L}$ of each oil, and then placed on the surface of inoculated plates $(90 \mathrm{~mm})$. Positive control discs of antibiotics commonly used for the treatment of respiratory tract diseases were tested. After $24 \mathrm{~h}$ of incubation at $37^{\circ} \mathrm{C}$, the inhibition zones were measured and expressed in $\mathrm{mm}$. All experiments were done in triplicate.

\section{Determination of MIC and MBC}

The minimal inhibition concentration (MIC) was studied only with oils which were proved to effective using the disc diffusion method (inhibition zones $\geq 17 \mathrm{~mm}$ ). MIC was determined using micro-well dilution method according to the protocol of Şahin et al. (2004) [16]. The 96-well plates were prepared by dispensing into each well $95 \mu \mathrm{L}$ of nutrient broth and $5 \mu \mathrm{L}$ of the inoculum. One-hundred microliters from each extract were initially prepared at a concentration of $0.166(\mathrm{v} / \mathrm{v})$ and added into the first well, followed by two-fold dilution until the $9^{\text {th }}$ well. The wells of column 10 were filled with $195 \mu \mathrm{L}$ of $\mathrm{MH}$ broth and reserved for the bacterial growth control, whereas the $11^{\text {th }}$ column wells were reserved for the control of the broth sterility. The wells of the last column were used as a negative control, and contained $195 \mu \mathrm{L}$ of nutrient broth and $5 \mu \mathrm{L}$ of the inoculum. The plates were screened visually after incubation at $37^{\circ} \mathrm{C}$ for $24 \mathrm{~h}$ for broth turbidity. The minimum bactericidal concentration $(\mathrm{MBC})$ is the lowest concentration of the essential oil that can kill $99.9 \%$ of the bacterial population after incubation for $18-24 \mathrm{~h}$ at $37^{\circ} \mathrm{C}[17,18]$. It was calculated by inoculating the content of the well indicating the MIC and the wells that precede it in an agar plate.

\section{Antifungal testing Fungal strains}

Seven Eucalyptus essential oils were tested against five fungal strains that comprise one opportunist pathogenic yeast (Candida albicans), one filamentous (Scopulariopsis brevicaulis) and three dermatophytes (Trichophyton rubrum, Trichophyton soudanense, Microsporum canis). The micro-organisms were obtained from the Laboratory of the Transmissible Diseases and Biological Active Substances LR99ES27 (Faculty of Pharmacy of Monastir, Tunisia).

\section{Agar incorporation method}

Antifungal activity was carried out by the agar incorporation method (dilution in a solid medium) including a negative control, as described previously by Bel Haj Salah et al. (2006) [19]. The test was performed in sterile Petri dishes $(33 \mathrm{~mm})$ containing Sabouraud Glucose Agar (SGA). Samples were mixed with ethanol 99\% (v/v) to obtain a final concentration of $1000 \mu \mathrm{L} / \mathrm{mL}$. This solvent was also used as a negative control. After cooling and solidification, the medium was inoculated with a small amount $(5 \mathrm{~mm})$ of a 7 day-old mycelium culture (for dermatophytes), a three days culture suspension adjusted to $10^{5}$ conidies/mL (Scopulariopsis brevicaulis) or a 3 day culture suspended in sterile distilled water and adjusted to $10^{5}$ spores $/ \mathrm{ml}$ (for yeasts). The pevaryl was used as anti-fungal reference. The Petri dishes were then incubated for additional seven days at $24^{\circ} \mathrm{C}$ for dermatophytes and for the filamentous, $24 \mathrm{~h}$ at $37^{\circ} \mathrm{C}$ for Candida. Three replications were carried out for each concentration and for each micro-organism. The antifungal activity of the essential oils was evaluated by 
calculating the percentage of inhibition (\% I) from the diameters of colonies in the control plate $(\mathrm{dC})$ and the colonies in the treated plate $(\mathrm{dE}) ; \% \mathrm{I}=(\mathrm{dC}-\mathrm{dE}) / \mathrm{dC}$, according to the method of Singh et al. (1993) [20].

\section{Cytotoxicity assay}

The evaluation of the cytotoxic effect of samples is based on the reduction of MTT (3-[4,5-dimethylthiazol-2-yl]2,5-diphenyl tetrazolium bromide), by the mitochondrial dehydrogenase of viable cells, to give a blue formazan product which can be measured spectrophotometrically at $540 \mathrm{~nm}$. The MTT colorimetric assay was performed in 96-well plates. Cells were seeded in 96-well plates at a concentration of $10^{5}$ cells per well and incubated for $24 \mathrm{~h}$ at $37^{\circ} \mathrm{C}$ in a $5 \% \mathrm{CO}_{2}$ humidified atmosphere. After treatment with various concentrations of the test compound, the cells were incubated for an additional $48 \mathrm{~h}$ at $37^{\circ} \mathrm{C}$. The cells were examined daily under a phasecontrast microscope to determine the minimum concentration of compounds that induced alterations in cell morphology. After that, the medium was removed and cells in each well were incubated with $100 \mu \mathrm{L}$ of MTT solution $(5 \mathrm{mg} / \mathrm{mL})$ for $3-4 \mathrm{~h}$ at $37^{\circ} \mathrm{C}$. Fifty microliters of dimethyl sulfoxide (DMSO) were then added to dissolve insoluble formazan crystal and the plates were incubated at $37^{\circ} \mathrm{C}$ for $30 \mathrm{~min}$. Optical density (OD) was measured at $540 \mathrm{~nm}$ using a Perkin-Elmer ELISA reader (HTS 7000 plus). Data were obtained from duplicate wells. Cell viability was expressed with respect to the absorbance of the control wells (untreated cells), which were considered as $100 \%$ of absorbance. The percentage of cytotoxicity is calculated as $[(\mathrm{A}-\mathrm{B}) / \mathrm{A}] \mathrm{x} 100$, where $A$ and $B$ are the $O_{540}$ of untreated and of treated cells, respectively. The percentage of viability was carried out using the formula: 100 - \% cytotoxicity. The $50 \%$ cytotoxic concentration $\left(\mathrm{CC}_{50}\right)$ was defined as the compound's concentration $(\mu \mathrm{g} / \mathrm{mL})$ required for the reduction of cell viability by $50 \%$, which were calculated by regression analysis $[y=f(x)$; where $y=\%$ viability and $\mathrm{x}=$ concentration of extract, $\mu \mathrm{g} / \mathrm{mL}$ ]. The used definition of the cytotoxicity, as supported by other reports [21] was; $\mathrm{CC}_{50}<1.0 \mu \mathrm{g} / \mathrm{mL}-$ high cytotoxicity; $\mathrm{CC}_{50}=1.0$ $10.0 \mu \mathrm{g} / \mathrm{mL}$ - moderate; $\mathrm{CC}_{50}=10.0-20.0 \mu \mathrm{g} / \mathrm{mL}-$ mild cytotoxicity; and $\mathrm{CC}_{50}>20 \mu \mathrm{g} / \mathrm{mL}$ - non cytotoxic.

\section{Antiviral activity}

Cell culture and virus. The Vero cell line was maintained in RPMI 1640 (Gibco, Tunisia) supplemented to fetal bovine serum $(10 \%, \mathrm{v} / \mathrm{v})$, L-Glutamin $(2 \mathrm{mM})$, penicillin $(100 \mathrm{U} / \mathrm{mL})$, and streptomycin $(100 \mu \mathrm{g} / \mathrm{mL})$. Cells were incubated at $37^{\circ} \mathrm{C}$ in a $5 \% \mathrm{CO}_{2}$ humidified atmosphere. Coxsakievirus B3 Nancy strain (kindly provided by Pr. Bruno Pozzetto, Laboratory of Bacteriology-
Virology, Saint-Etienne, France) was propagated in Vero cells.

Confluent Vero cell cultures were treated with three non cytotoxic concentrations of the essential oil during and after virus infection in two sets of experiments as follows: (1) $5 \times 10^{4} \mathrm{TCID}_{50}$ of the virus was exposed to essential oil for one hr at $37^{\circ} \mathrm{C}$. Then $100 \mu \mathrm{L}$ of the mixture were added to the cells cultured fluently in 96-well flat-bottom microtiter plate $(100 \mu \mathrm{L})$; (2) Cells were treated with essential oil $(100 \mu \mathrm{L})$ for one $\mathrm{hr}$ at $37^{\circ} \mathrm{C}$. After one hr of incubation at $37^{\circ} \mathrm{C}, 5 \times 10^{4} \mathrm{TCID}_{50}$ of the virus $(100 \mu \mathrm{L})$ were added.

All plates were incubated at $\mathrm{CO}_{2}$-incubator for $48 \mathrm{hrs}$. The viability of the infected and non-infected cells was evaluated according to the absorbance values of formazan using the MTT inclusion assay, as described in cytotoxicity assay. The percentage of protection was calculated as follows:

Percent protection $=[(\mathrm{ODT})-(\mathrm{ODC}) \mathrm{V}] /[(\mathrm{ODC}) \mathrm{M}-$ $(\mathrm{ODC}) \mathrm{V}] \times 100$

Where (ODT), (ODC) $\mathrm{V}$ and (ODC) $\mathrm{M}$ indicate $\mathrm{ab}$ sorbance of the test sample, the virus-infected control (no compound) and mock-infected control (no virus and no compound), respectively. The $50 \%$ inhibition concentration $\left(\mathrm{IC}_{50}\right)$ was calculated by regression curve analysis, which is defined as the concentration of the essential oil that inhibits the viral infection by $50 \%$ [22].

\section{Statistical analysis}

The data were analyzed using analysis of variance (ANOVA). The significance of the differences between means was determined at $p<0.05$ using Duncan's multiple range tests. Results were expressed as means \pm Standard Deviation (SD). To evaluate whether the identified components may be useful in reflecting chemotaxonomic and biological activities relationships, 25 compounds detected in the oil samples at an average concentration greater than $0.9 \%$ of the total oil were selected and used for this purpose. Both of these components and all the values of the essential oils zone diameters of bacteria growth inhibition were subjected to a principal component analysis (PCA) and to hierarchical cluster analysis (HCA) using SPSS 12.0 software (SPSS Inc. Chicago, IL, USA). To evaluate the antiviral activity in vitro, the selectivity index $\left(\mathrm{SI}=\mathrm{CC}_{50} / \mathrm{IC}_{50}\right)$ was determined. The selectivity index describes the ratio between the cytotoxic and the antiviral activity of a tested compound.

\section{Results and discussion Chemical composition}

The chromatographic analysis (GC retention index (RI) and $\mathrm{GC} / \mathrm{MS}$ ) of the essential oils allowed the identification of 144 components representing 87.40 to $99.37 \%$ of 
the total oil content [23-25]. Twenty five major compounds at an average concentration greater than $0.9 \pm 0,2 \%$ have been retained for the statistical analysis (Table 1). The main components were 1,8-cineole $(4.5 \pm 1,61-70.4 \pm 2.5 \%)$ followed by cryptone (0.0 $20.9 \pm 1.3 \%), \alpha$-pinene $(1.0 \pm 0.7-17.6 \pm 7.5 \%), p$-cymene $(0.8 \pm 0.1-16.7 \pm 5.2 \%), \alpha$-terpineol $(0,6 \pm 0,3-10,3 \pm 1,1 \%)$, trans-pinaocarveol $(0.8 \pm 0.2-7.0 \pm 2.5 \%)$, phellandral $(0.0-6.6 \pm 0.4 \%)$, cuminal $(0.0-6.6 \pm 0,6 \%)$, globulol $(0.6 \pm 0.2-6.2 \pm 0.9 \%)$, limonene $(0.4 \pm 0.2-4.4 \pm 0.3 \%)$, aromadendrene $(0.1 \pm 0.0-3.6 \pm 1.2 \%)$, sapthulenol $(0.1 \pm 0.1-3.2 \pm 0.9 \%)$ and terpinene-4-ol $(0.3 \pm 0.1$ $3.0 \pm 0.8 \%)$.

\section{Principal components analysis (PCA) and hierarchical cluster analysis (HCA)}

The yield content of the 25 selected component was significantly different $(p<0.05)$ among species (Table 1$)$.
These 25 components were used for the PCA and the HCA analysis. The PCA horizontal axis explained $47.2 \%$ of the total variance while the vertical axis a further $23.80 \%$ (Figure 1). The HCA based on the Euclidean distance between groups indicated three specie groups (A, B and C) (with a dissimilarity of 11.0) (Figure 2), identified by their essential oil chemotypes. Group A clearly stood out forming a separate group in the PCA (Figure 1) and a deep dichotomy in the HCA (Figure 2). It was correlated positively with the axes 1 and 2. Groups A and B were negatively correlated, their separation was mainly due to axis 2 . Group A species reduced to $E$. odorata, the essential oil of which was characterized by the highest mean percentage of cryptone $(20.9 \pm 1.3 \%)$, cuminal $(6.6 \pm 0.6 \%)$, phellandral $(6.6 \pm 0.4 \%), \quad$ verbenone $\quad(0.9 \pm 0.2 \%), \quad p$-cymen- 8 -ol $(2.9 \pm 0.6 \%)$, sapthulenol $(3.2 \pm 0.9 \%)$, carvacrol $(1.7 \pm 0.3 \%)$, $p$-cymene $(16.7 \pm 5.2 \%)$, terpinene-4-ol $(3.0 \pm 0.8 \%)$, caryophyllene oxyde $(1.7 \pm 0.2 \%)$, viridiflorol $(4.5 \pm 1.6 \%)$ and by

Table 1 Contents (\%) of the 25 major compounds of the essential oils, extracted from the leaves of 8 Eucalyptus species, selected for the Principal Components and the Hierarchical Clusters Analyses

\begin{tabular}{|c|c|c|c|c|c|c|c|c|c|c|}
\hline \multirow[t]{2}{*}{ № } & \multirow[t]{2}{*}{ Compounds } & \multirow[t]{2}{*}{ Abbreviations } & \multicolumn{8}{|c|}{ Content $^{a}(\%)$} \\
\hline & & & E. maid $^{b}$ & E. cin & E. sid & E. odo & E. bic & E. leh & E. astr & E. leuc \\
\hline 1. & a-Pinene & a-pin & $7.3 \pm 0.7$ & $4.5 \pm 0.7$ & $6.9 \pm 1.1$ & $1.0 \pm 0.7$ & $3.7 \pm 1.2$ & $17.6 \pm 7.5$ & $22.0 \pm 6.0$ & $7.8 \pm 2.3$ \\
\hline 2. & Limonene & $\lim$ & $3.1 \pm 0.2$ & $3.7 \pm 0.5$ & $4.1 \pm 0.1$ & $0.4 \pm 0.2$ & $0.9 \pm 0.5$ & $4.4 \pm 0.3$ & $1.4 \pm 0.3$ & $2.0 \pm 0.5$ \\
\hline 3. & 1.8-Cineole & $1.8-\operatorname{cin}$ & $57.8 \pm 1.9$ & $70.4 \pm 2.5$ & $69.2 \pm 0.6$ & $4.5 \pm 1.6$ & $68.0 \pm 5.3$ & $56.6 \pm 4.3$ & $42.0 \pm 5.9$ & $59.2 \pm 10.1$ \\
\hline 4. & $\gamma$-Terpinene & $\gamma$-ter & $1.7 \pm 0.9$ & $0.1 \pm 0.0$ & $0.1 \pm 0.0$ & $0.2 \pm 0.2$ & $0.1 \pm 0.1$ & $0.9 \pm 0.2$ & $0.1 \pm 0.1$ & $0.2 \pm 0.4$ \\
\hline 5. & p-Cymene & p-cym & $7.4 \pm 2.9$ & $1.2 \pm 0.1$ & $0.8 \pm 0.1$ & $16.7 \pm 5.2$ & $1.4 \pm 0.5$ & $2.0 \pm 0.2$ & $0.9 \pm 0.2$ & $2.9 \pm 3.4$ \\
\hline 6. & Pinocarvone & pin & $0.5 \pm 0.2$ & $0.3 \pm 0.1$ & $0.2 \pm 0.0$ & $0.2 \pm 0.1$ & $2.2 \pm 0.5$ & $0.2 \pm 0.0$ & $1.8 \pm 0.8$ & $1.2 \pm 0.2$ \\
\hline 7. & Terpinene-4-ol & Ter-4ol & $1.1 \pm 0.3$ & $0.4 \pm 0.1$ & $0.6 \pm 0.0$ & $3.0 \pm 0.8$ & $0.2 \pm 0.1$ & $0.3 \pm 0.1$ & $0.4 \pm 0.1$ & $0.2 \pm 0.2$ \\
\hline 8. & Aromadendrene & aro & $1.6 \pm 0.8$ & $0.1 \pm 0.0$ & $0.5 \pm 0.2$ & $0.4 \pm 0.0$ & $2.0 \pm 0.8$ & $0.2 \pm 0.0$ & $3.6 \pm 1.2$ & $2.1 \pm 1.4$ \\
\hline 9. & tr-Pinocarveol & tr-pin & $2.0 \pm 0.8$ & $1.0 \pm 0.2$ & $1.2 \pm 0.1$ & $0.8 \pm 0.2$ & $4.6 \pm 0.6$ & $1.0 \pm 0.2$ & $7.0 \pm 2.5$ & $4.3 \pm 1.0$ \\
\hline 10. & Cryptone & cry & - & - & $\operatorname{tr} \pm 0.1$ & $20.9 \pm 1.3$ & - & - & $0.1 \pm 0.1$ & - \\
\hline 11. & a-Terpineol & $a$-ter & $2.2 \pm 0.2$ & $10.3 \pm 1.1$ & $5.4 \pm 0.9$ & $0.8 \pm 0.2$ & $0.6 \pm 0.3$ & $8.7 \pm 2.5$ & $1.3 \pm 0.3$ & $1.6 \pm 0.7$ \\
\hline 12. & Verbenone & ver & - & - & $\operatorname{tr} \pm 0.1$ & $0.9 \pm 0.2$ & - & - & $0.1 \pm 0.1$ & - \\
\hline 13. & Phellandral & phe & - & $0.2 \pm 0.2$ & - & $6.6 \pm 0.4$ & $0.2 \pm 0.2$ & - & - & - \\
\hline 14. & Cuminal & cum & - & $0.1 \pm 0.0$ & - & $6.6 \pm 0.6$ & - & - & - & - \\
\hline 15. & tr-p-Mentha-1.7. 8dien-2-ol & tr-p-men & $0.5 \pm 0.1$ & $1.0 \pm 0.2$ & $0.6 \pm 0.0$ & $0.5 \pm 0.1$ & $1.0 \pm 0.1$ & $0.2 \pm 0.1$ & $0.4 \pm 0.1$ & $0.8 \pm 0.1$ \\
\hline 16. & p-Cymen-8-ol & p-cym & $0.1 \pm 0.0$ & $0.1 \pm 0.0$ & $0.1 \pm 0.0$ & $2.9 \pm 0.6$ & $0.1 \pm 0.0$ & $\operatorname{tr} \pm 0.1$ & $0.1 \pm 0.0$ & $0.1 \pm 0.1$ \\
\hline 17. & cis-p-Mentha-1. 7. 8dien-2-ol & cis-men & $0.4 \pm 0.2$ & $1.0 \pm 0.2$ & $0.6 \pm 0.0$ & $0.1 \pm 0.1$ & $1.0 \pm 0.1$ & $0.3 \pm 0.2$ & $0.4 \pm 0.1$ & $0.8 \pm 0.1$ \\
\hline 18. & Caryophyllene oxide & car-ox & $0.1 \pm 0.0$ & $\operatorname{tr} \pm 0.1$ & $0.1 \pm 0.1$ & $1.7 \pm 0.2$ & $\operatorname{tr} \pm 0.1$ & $0.1 \pm 0.1$ & $0.1 \pm 0.0$ & $\operatorname{tr} \pm 0.1$ \\
\hline 19. & Epiglobulol & epi & $0.4 \pm 0.2$ & $0.1 \pm 0.1$ & $0.1 \pm 0.0$ & $\operatorname{tr} \pm 0.1$ & $1.0 \pm 0.2$ & $0.1 \pm 0.0$ & $1.2 \pm 0.3$ & $1.1 \pm 0.6$ \\
\hline 20. & Globulol & glo & $1.7 \pm 1.4$ & $0.6 \pm 0.2$ & $1.1 \pm 0.3$ & $0.8 \pm 0.2$ & $5.4 \pm 1.2$ & $0.6 \pm 0.2$ & $6.2 \pm 0.9$ & $5.8 \pm 2.9$ \\
\hline 21. & Viridiflorol & vir & $0.7 \pm 0.3$ & $0.2 \pm 0.1$ & $0.4 \pm 0.1$ & $1.0 \pm 0.3$ & $0.8 \pm 0.2$ & $0.2 \pm 0.1$ & $1.1 \pm 0.1$ & $0.8 \pm 0.4$ \\
\hline 22. & Spahulenol & spa & $0.1 \pm 0.1$ & $0.2 \pm 0.1$ & $0.5 \pm 0.3$ & $3.2 \pm 0.9$ & $0.1 \pm 0.0$ & $1.0 \pm 0.1$ & $0.9 \pm 0.1$ & $0.1 \pm 0.1$ \\
\hline 23. & Carvacrol & car & $0.4 \pm 0.1$ & $0.1 \pm 0.0$ & $0.1 \pm 0.0$ & $1.7 \pm 0.3$ & $0.1 \pm 0.0$ & $0.2 \pm 0.0$ & $0.2 \pm 0.1$ & $0.3 \pm 0.3$ \\
\hline 24. & a-Eudesmol & a-eud & $1.1 \pm 0.6$ & - & $0.4 \pm 0.1$ & - & $0.1 \pm 0.0$ & $0.3 \pm 0.1$ & $0.1 \pm 0.0$ & $0.2 \pm 0.1$ \\
\hline 25. & $\beta$-Eudesmol & $\beta$-eud & $3.0 \pm 1.9$ & $0.2 \pm 0.0$ & $0.6 \pm 0.1$ & $0.1 \pm 0.2$ & $\operatorname{tr} \pm 0.1$ & $0.3 \pm 0.1$ & $0.1 \pm 0.0$ & $0.1 \pm 0.2$ \\
\hline
\end{tabular}

\footnotetext{
${ }^{a}$ Values are means $\pm S D$ of triplicate determination.
}

${ }^{\mathrm{b}}$ E. maid $=E$. maidenii, E. cin $=E$. cinerea, E. Sid $=E$. sideroxylon, E. odo $=E$. odorata, E. bic $=E$. bicostata, E. leh $=E$. lehmannii, E. ast $=E$. astringens, E. leuc $=E$. leucoxylon. 


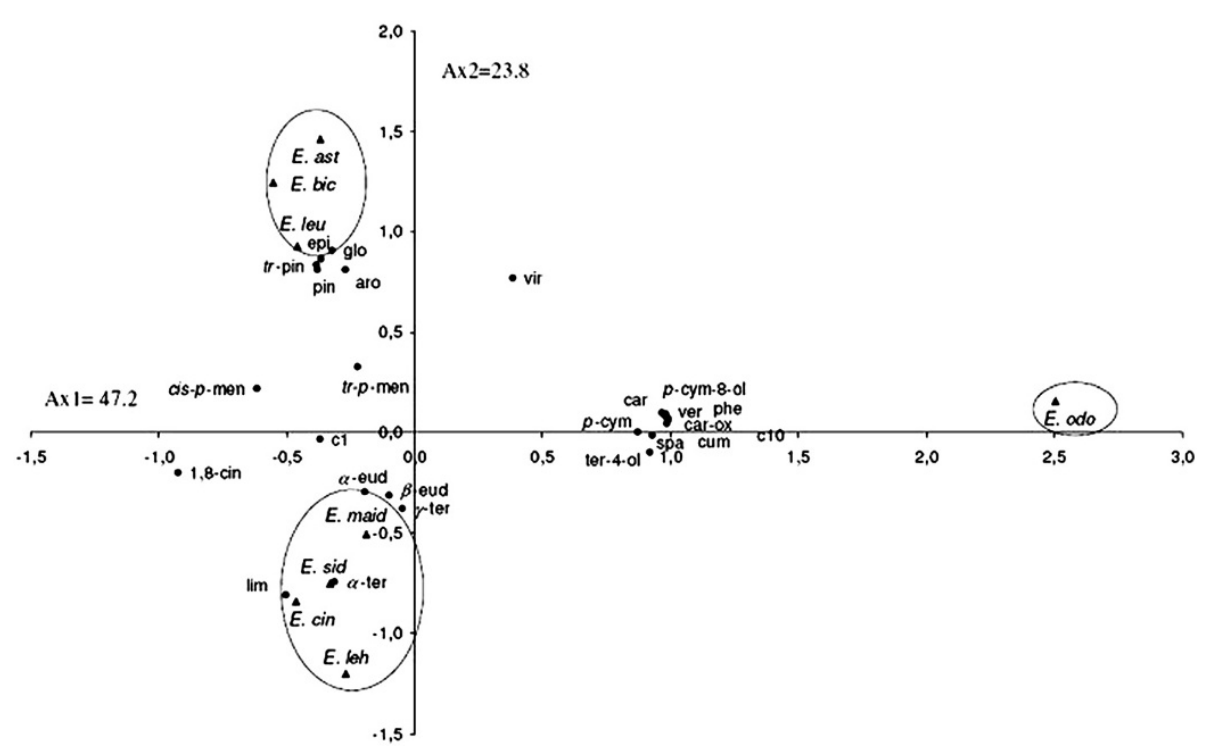

Figure 1 ACP of the $\mathbf{2 6}$ major components of eight eucalyptus essential oils. For the abbreviation of Eucalyptus species ( $\mathbf{\Lambda})$ and components $(\bullet)$ see Table 1.

the lowest level of 1,8-cineole ( $4.5 \pm 1.6 \%)$. Group B, made up of E. maidenii, E. lehmannii, E. sideroxylon and E. cinerea, has essential oils characterized by the highest amount of limonene ( $3.1 \pm 0.2$ to $4.4 \pm 0.2 \%)$, $\alpha$-terpineol $(2.2 \pm 0.3 \%$ for $E$. maidenii to $10.3 \pm 1.1 \%$ for E. cinerea). The PCA showed that the variation between these species is mainly due to the variation of 1,8 -cineole content $(57.8 \pm 1.9 \%$ for E. maidenii to $70.4 \pm 2.5$ for E. cinerea) and of $\alpha$-pinene (4.5 $\pm 0.7 \%$ for E. cinerea to $17.6 \pm 7.5 \%$ for E. lehmannii). Group C, consisting of E. astringens, E. leucoxylon and $E$. bicostata, has essential oils distinguished by their highest mean percentage of epiglobulol (1.0 $\pm 0.2-1.2 \pm 0.3 \%)$, globulol (5.4 $\pm 1.2-6.2 \pm 0.9 \%)$, trans-pinocarveol $(4.3 \pm 1.0$ to $7.0 \pm 2.5 \%)$, aromadendrene $(2.0 \pm 0.8-3.6 \pm 1.2 \%)$ and pinocarvone $(1.2 \pm 0.2-2.2 \pm 0.5 \%)$. The E. bicostata and E. leucoxylon oils differed from $E$. astringens oil by their richness in 1,8 -cineole $(68.0 \pm 5.3,59.2 \pm 10.1 \%$, respectively) and their poverty in $\alpha$-pinene $(3.7 \pm 1.2$, $7.8 \pm 2.3 \%$, respectively) against $42.0 \pm 5.9 \%$ and $22.0 \pm 6.0 \%$, respectively for the latter species.

As in the present study, E. cinerea, E. sideroxylon, $E$. bicostata, E. maidenii, E. leucoxylon, E. lehmannii and $E$. astringens have been reported to contain 1,8-cineole as a major component [26-30]. It was also reported that $E$. cinerea grown in Morocco contained a higher mean percentage of 1,8-cineole (87.8\%) than that from Tunisia (70.4-2.5\%) [27], whereas E. sideroxylon acclimated in Tunisia was richer in 1,8-cineole (69.2-0.6\%) than that from Congo (59.9\%) [31]. The Tunisian E. astringens essential oil had the same chemotype as that extracted from leaves picked from Moroccan tree plantations with an important difference in their mean percentages. Both

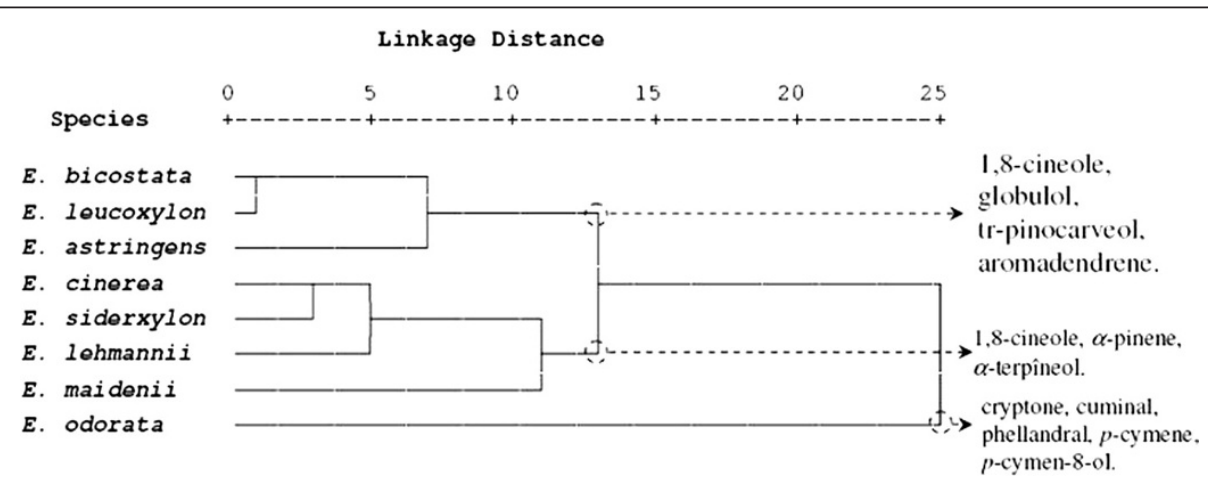

Figure 2 Dendrogram obtained by hierarchical cluster analysis based on the Euclidean distance between groups of leaf essential oils of eight Tunisian Eucalyptus species. Components that characterise the major sub groups, considered as chemotypes, are indicated. 
of them were different from the Australian E. astringens essential oil [32], which was represented by $\beta$-caryophyllene (14.75\%), $p$-cymene (17.72\%), and $\alpha$-pinene (12.53\%). The same principal components were also observed in $E$. leucoxylon essential oil [33,34], whereas the essential oil obtained from Iran was significantly richer in 1,8-cineole (89.8\%) than that from Tunisia [33].

\section{Antibacterial activity}

The essential oils were tested for their putative antibacterial activity against seven bacterial isolates represented by 81 strains (Table 2). As shown in Table 2, E. odorata oil possessed the best activity against $S$. aureus $(27.4 \pm 10.7 \mathrm{~mm}$, zdi), followed by $S$. agalactiae $(19.4 \pm 5.6 \mathrm{~mm}$, zdi), $H$. influenzae $(19.2 \pm 9.6 \mathrm{~mm}, \mathrm{zdi}), S$. pyogenes $(19.0 \pm 0.0 \mathrm{~mm}, \mathrm{zdi})$ and S. pneumoniae (17.4 $\pm 4.1 \mathrm{~mm}$, zdi). E. maidenii oil showed a relatively good activity against $S$. aureus $(22.8 \pm 6.8 \mathrm{~mm}$, zdi).
To evaluate the correlation between the antibacterial activities and the essential oils of the eight Eucalyptus species, all the mean values of the zone diameters inhibition were subject to the PCA and the HCA analysis. The statistical analysis of the antibacterial activities of the oils showed a significant difference among Eucalyptus species oils and the tested bacterial strains $(p<0.05)$. The PCA horizontal axis explained $59.39 \%$ of the total variance, while the vertical axis a further $13.84 \%$ (Figure 3 ). The HCA showed two species groups (I and II), identified by their bacteria growth inhibition with a dissimilarity $\geq 15.0$ (Figure 4 ). When the dissimilarity was $\geq 5.0$, group II was divided into three subgroups $\left(\mathrm{II}_{\mathrm{a}}, \mathrm{II}_{\mathrm{b}}\right.$ and $\left.\mathrm{II}_{\mathrm{c}}\right)$. The horizontal axis permitted the separation of group I from group II, however axis II separated all the species of the group II into three subgroups. Group I, limited to the Gram negative $(\operatorname{Gram}(-))$ bacteria, $P$. aeruginosa and $K$. pneumoniae,

Table 2 Diameter of the inhibition of respiratory bacterial growth by essential oils and by antibiotics*

\begin{tabular}{|c|c|c|c|c|c|c|c|}
\hline \multirow[t]{2}{*}{ Essential oils } & \multicolumn{7}{|c|}{ Tested microorganisms (number of strains) } \\
\hline & $\begin{array}{c}\text { H. influenzae } \\
\text { (11) }\end{array}$ & $\begin{array}{c}\text { K. pneumoniae } \\
\text { (13) }\end{array}$ & $\begin{array}{c}\text { P. aeruginosa } \\
\text { (10) }\end{array}$ & $\begin{array}{l}\text { S. aureus } \\
\text { (17) }\end{array}$ & $\begin{array}{c}\text { S. agalactiae } \\
\text { (9) }\end{array}$ & $\begin{array}{c}\text { S. pneumoniae } \\
\text { (19) }\end{array}$ & $\begin{array}{c}\text { S. pyogenes } \\
\text { (4) }\end{array}$ \\
\hline E. maidenii & $14.5 \pm 5.7^{\mathrm{bc} \cdot)}$ & $10.7 \pm 1.5^{\mathrm{ab}}$ & $7.1 \pm 1.5^{\mathrm{a}}$ & $22.8 \pm 6.8^{d}$ & $13.8 \pm 2.2^{\mathrm{bc}}$ & $13.0 \pm 2.6^{\mathrm{bc}}$ & $15.5 \pm 4.0^{c}$ \\
\hline E. odorata & $19.2 \pm 9.6^{b}$ & $10.8 \pm 1.2^{\mathrm{a}}$ & $6.0 \pm 0.0^{\mathrm{a}}$ & $27.4 \pm 10.7^{c}$ & $19.4 \pm 5.6^{b}$ & $17.4 \pm 4.1^{\mathrm{b}}$ & $19.0 \pm 0.0^{b}$ \\
\hline E. lehamnnii & $11.5 \pm 3.3^{\mathrm{bc}}$ & $6.8 \pm 0.7^{\mathrm{a}}$ & $6.5 \pm 0.8^{\mathrm{a}}$ & $14.2 \pm 4.8^{c}$ & $11.1 \pm 1.4^{\mathrm{b}}$ & $9.8 \pm 2.4^{b}$ & $11.5 \pm 1.7^{\mathrm{bc}}$ \\
\hline E. leucoxylon & $8.1 \pm 2.2^{\mathrm{a}}$ & $6.6 \pm 1.1^{\mathrm{a}}$ & $6.0 \pm 0.0^{\mathrm{a}}$ & $16.4 \pm 5.4^{c}$ & $12.9 \pm 1.8^{b}$ & $14.4 \pm 3.0^{\mathrm{bc}}$ & $9.0 \pm 0.0^{\mathrm{a}}$ \\
\hline E. bicostata & $13.6 \pm 5.0^{\mathrm{b}}$ & $7.1 \pm 1.4^{\mathrm{a}}$ & $6.0 \pm 0.0^{a}$ & $15.6 \pm 2.8^{b c}$ & $13.8 \pm 2.8^{b}$ & $17.0 \pm 4.0^{c}$ & $13.0 \pm 0.0^{b}$ \\
\hline E. astringens & $13.0 \pm 3.8^{\mathrm{bc}}$ & $7.1 \pm 1.6^{\mathrm{a}}$ & $6.0 \pm 0.0^{\mathrm{a}}$ & $15.5 \pm 5.2^{c}$ & $12.0 \pm 3.2^{b}$ & $12.3 \pm 12.3^{b c}$ & $12.5 \pm 1.7^{\mathrm{bc}}$ \\
\hline E. cinerea & $13.0 \pm 6.3^{b}$ & $8.5 \pm 2.2^{a}$ & $6.2 \pm 0.6^{a}$ & $12.2 \pm 2.8^{b}$ & $11.6 \pm 1.4^{b}$ & $11.5 \pm 2.8^{b}$ & $12.5 \pm 1.7^{b}$ \\
\hline E. sideroxylon & $12.3 \pm 8.4^{b}$ & $8.1 \pm 1.8^{\mathrm{a}}$ & $7.0 \pm 1.5^{\mathrm{a}}$ & $13.7 \pm 3.8^{b}$ & $12.3 \pm 1.6^{b}$ & $10.7 \pm 2.5^{\mathrm{ab}}$ & $12.0 \pm 0.0^{b}$ \\
\hline \multicolumn{8}{|c|}{ Reference antibiotics } \\
\hline Ampicillin & $30.5 \pm 6.1^{c}$ & NT & NT & NT & NT & NT & NT \\
\hline $\begin{array}{l}\text { Benzylpenicillin } \\
\text { (Penicillin G) }\end{array}$ & NT & NT & NT & $24.5 \pm 7.5^{a}$ & NT & NT & NT \\
\hline Ceftazidime & NT & $22.3 \pm 7.5^{\mathrm{a}}$ & $23.8 \pm 5.6^{\mathrm{a}}$ & NT & NT & NT & NT \\
\hline Cehotaxime & $20.7 \pm 6.0^{b}$ & NT & NT & NT & NT & NT & NT \\
\hline Ciprofloxacin & NT & $32.4 \pm 2.9^{b}$ & $34.7 \pm 5.0^{b}$ & NT & NT & NT & $\mathrm{Nt}$ \\
\hline Erythromycin & $19.9 \pm 4.2^{b}$ & NT & NT & $29.9 \pm 5.1^{\mathrm{ab}}$ & $29.2 \pm 4.2^{b}$ & $26.3 \pm 12.0^{a}$ & $29.0 \pm 0.0^{c}$ \\
\hline Fosfomycin & NT & $22.1 \pm 2.9^{\mathrm{a}}$ & NT & $34.3 \pm 11.1^{c}$ & $27.9 \pm 5.9^{\mathrm{ab}}$ & $35.6 \pm 5.5^{c}$ & $24.5 \pm 0.8^{a}$ \\
\hline Gentamicin & NT & $22.9 \pm 5.0^{\mathrm{a}}$ & NT & $29.6 \pm 6.2^{\mathrm{ab}}$ & NT & NT & NT \\
\hline Imipenem & NT & NT & $24.6 \pm 6.6^{a}$ & NT & NT & NT & NT \\
\hline Levofloxacin & NT & NT & NT & NT & $24.8 \pm 2.8^{\mathrm{a}}$ & $27.3 \pm 3.5^{\mathrm{ab}}$ & $25.0 \pm 1.5^{\mathrm{ab}}$ \\
\hline Lincomycin & $11.3 \pm 1.8^{\mathrm{a}}$ & NT & NT & NT & NT & NT & NT \\
\hline Oxacillin & NT & NT & NT & NT & $33.6 \pm 4.2^{c}$ & $31.7 \pm 11.9^{\mathrm{abc}}$ & $30.0 \pm 0.0^{c}$ \\
\hline Piperacillin & NT & NT & $25.3 \pm 7.3^{a}$ & NT & NT & NT & NT \\
\hline Rifamycin & $23.9 \pm 4.7^{b}$ & NT & NT & NT & $34.4 \pm 4.3^{c}$ & $37.5 \pm 8.1^{c}$ & $31.5 \pm 0.8^{d}$ \\
\hline Tetracyclin & $29.2 \pm 2.6^{c}$ & NT & $24.4 \pm 6.1^{\mathrm{a}}$ & NT & NT & NT & NT \\
\hline Vancomycin & NT & NT & $\mathrm{Nt}$ & $25.3 \pm 4.4^{\mathrm{a}}$ & $26.3 \pm 3.4^{\mathrm{ab}}$ & $33.0 \pm 3.5^{b c}$ & $26.0 \pm 2.0^{b}$ \\
\hline
\end{tabular}

"Values are means (mm. \pm SD) of triplicate determination.

-) Values with different letters differ significantly by Duncan's multiple range test $(p<0.05)$.

$\mathrm{NT}=$ Not tested 


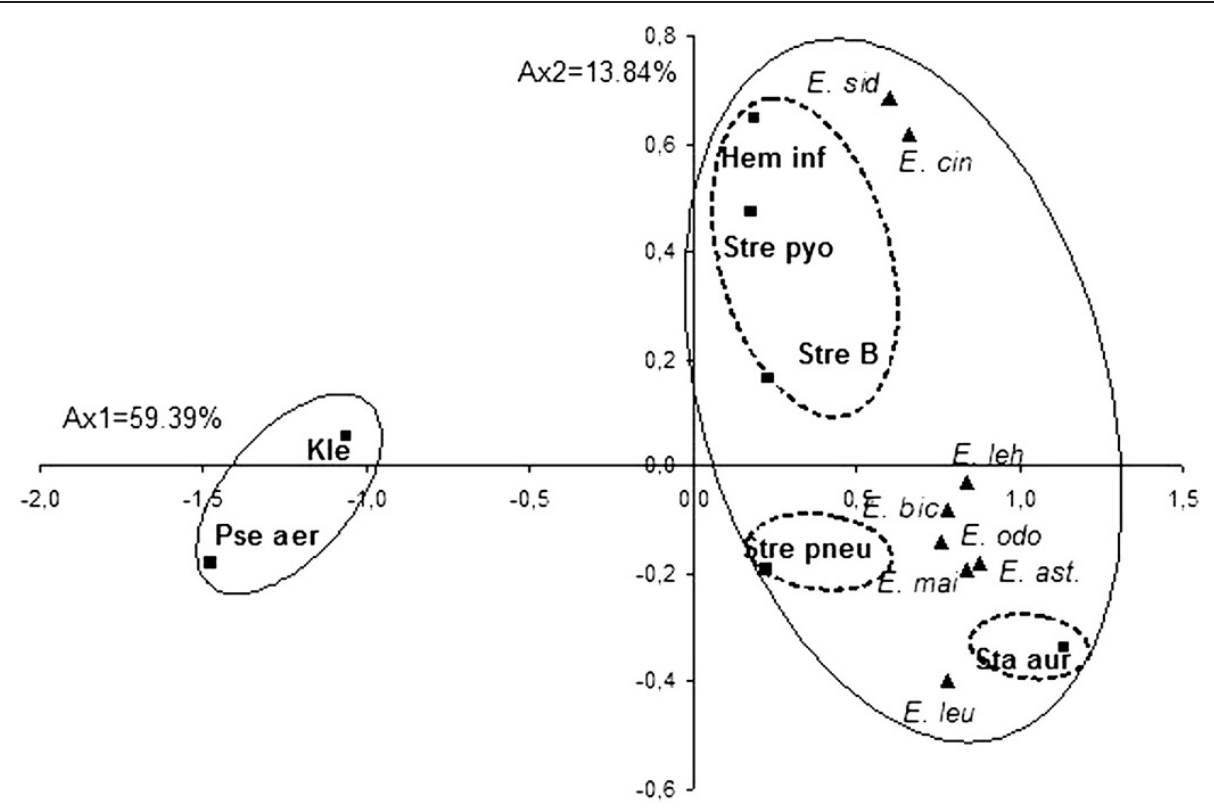

Figure 3 PCA of the antibacterial activity of 08 Eucalyptus essential oils species against seven clinical bacteria ( $\square$ ). For the abbreviation of the Eucalyptus species ( $\mathbf{\Delta}$ ) see Table 1.-) Hem inf=Haemophylis influenza, kle=Klebsiella pneumoniae = Pse aer: Pseudomans aeruginosa, sta aur =Staphylococcus aureus, Stre B=Streptococcus agalactiae, Stre pneu=Streptococcus pneumoniae, Strep pyo=Streptococcus pyogenes.

forms a deep dichotomy within the HCA analysis and a clearly separated group in the PCA analysis. These two strains were the most resistant to the majority of Eucalyptus essential oils with $\mathrm{zdi}<7.1 \mathrm{~mm}$ for $P$. aeruginosa and $10.7 \pm 1.5 \mathrm{~mm}$ for $K$. pneumoniae. Compared to the growth inhibition zone produced by ciprofloxacin against $P$. aeruginosa $(34.7 \pm 5.0 \mathrm{~mm}$, zdi) and $K$. pneumoniae $(32.4 \pm 2.9 \mathrm{~mm}$, zdi). Subgroup Ia was limited to $S$. aureus which was characterized by the highest sensitivity to $E$. maidenii and E. odorata oils (22.8 \pm 6.8 and $27.4 \pm 10.7 \mathrm{~mm}$, zdi, respectively). This high sensitivity could be due to the disposition of E. maidenii and E. odorata oils with a relatively high mean percentage of the monoterpene hydrocarbons $p$-cymene $(7.4 \pm 2.9,16.7 \pm 5.2 \%$, respectively). Previous studies have reported the high sensitive character of S. aureus to essential oils with a high content of $p$-cymene [35]. In addition, other researchers reported that this sensitivity of $S$. aureus was due to the single layer wall of the bacteria [36]. Comparing these results with those obtained with antibiotics, E. odorata essential oil produced a similar inhibition to that produced by gentamicin, erythromycin, vancomycin and benzylpenicillin (29.6 \pm 6.2 , $29.9 \pm 5.1,25.3 \pm 4.4$ and $24.5 \pm 7.5 \mathrm{~mm}$, dzi, respectively). However, this activity remained lower than that produced by fosfomycin $(34.3 \pm 11.1 \mathrm{~mm}$, dzi). Sub group IIb represented by $S$. pneumoniae, showed a particular sensitivity to E. odorata and E. bicostata essential oils (17.4 \pm 4.1 and $17.0 \pm 4.0 \mathrm{~mm}$, zdi). This inhibition remained lower than that produced by its specific antibiotics with zone diameters inhibition ranging from $26.3 \pm 12.0 \mathrm{~mm}$ (erythromycin) to $35.6 \pm 5.5 \mathrm{~mm}$ (fosfomycin). E. lehmannii, E. sideroxylon and E. cinerea oils did not show significant

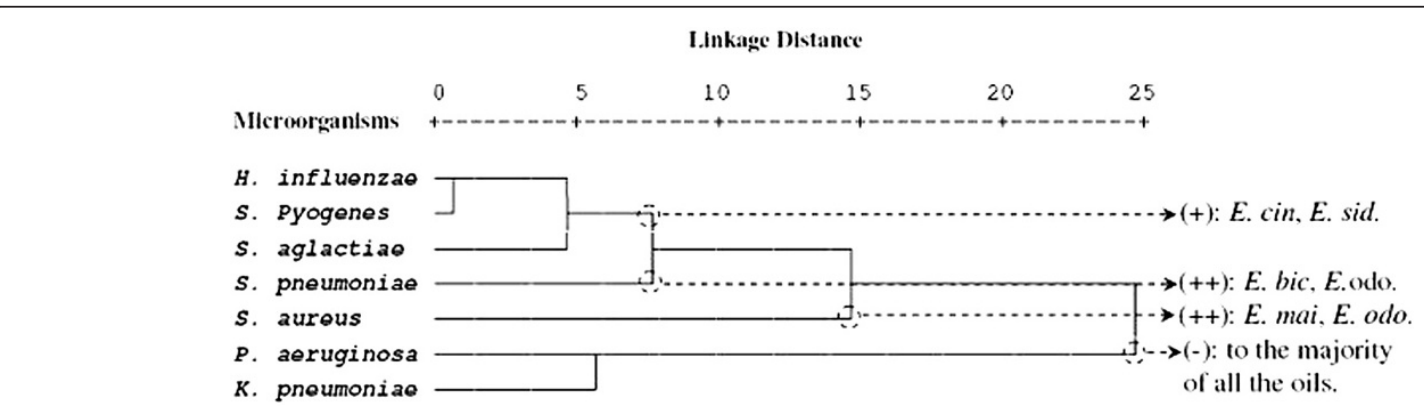

Figure 4 Dendrogram obtained by hierarchical cluster analysis based on the Euclidean distance between groups of the antibacterial activities of leaf essential oils of eight Tunisian Eucalyptus species. For the abbreviation of the Eucalyptus species ( $\mathbf{\Lambda})$, see Table 1. 
antibacterial activities with inhibition zones of $9.8 \pm 2.4$, $10.7 \pm 2.5$ and $11.5 \pm 2.8 \mathrm{~mm}$, respectively. Subgroup IIc, consists of Streptococcus B, S. pyogenes and H. influenzae. These strains were separated from all the others and correlated positively with the two axes and with E. cinerea and $E$. sideroxylon, the essential oils of which were characterized by a comparable activity against the previous bacterial strains, with inhibition zone diameters varying from $11.6 \pm 1.4 \mathrm{~mm}$ to $13.0 \pm 6.3 \mathrm{~mm}$. Their activities were considered relatively as being lower than the tested antibiotics such as rifamicine and ampicilline. However E. odorata oil, which was removed from this group, showed the best activity against these bacterial strains with inhibition zone diameters varying from $17.4 \pm 4.1 \mathrm{~mm}$ for $S$. pneumoniae to $19.4 \pm 5.6$ for Streptococcus B, but it remained much lower than that produced by their specific antibiotics. The MIC was performed for oils which have produced an inhibition $\geq 17 \mathrm{~mm}$ for clinical bacterial strains such as $H$. influenzae (reference 160), S. agalactiae (reference 3) S. pyogenes (reference 545) and S. aureus (reference 278). The result of their MIC was listed in Table 3. E. odorata and E. bicostata oils were characterized by the lowest MIC for Hemophylis influenzae (reference 160$)(0.306 \mathrm{mg} / \mathrm{mL})$, followed by $S$. agalactiae (reference 3$)(10.4 \mathrm{mg} / \mathrm{mL})$. These results were confirmed by the disc diffusion method. The highest MIC against S. aureus (reference 278) was shown for the oils of $E$. bicostata $(169 \mathrm{mg} / \mathrm{mL}), E$. odorata $(156.6 \mathrm{mg} / \mathrm{mL})$ and E. maidenii $(151.8 \mathrm{mg} / \mathrm{mL})$. This finding was in contradiction to results obtained by the disc diffusion method. According to the classification of Schaechter et al. (1999) [37] and Soro et al. (2010) [38], E. odorata, E. bicosta and E. maidenii oils were considered bactericidal $(\mathrm{MBC} / \mathrm{MIC}<4)$ against the tested strains, however the two first oils showed a better bactericidal activity against $H$. influenzae (reference 160) and S. aureus (reference 278) than that obtained with S. pyogens (reference 545) and S. aglatctiae (reference 3).

\section{Antifungal activity}

Seven Eucalyptus oils were tested for their antifungal and anti-yeast activities. The result of their average percentages inhibition was listed in Table 4 . Their variance analysis showed a highly significant effect for all oils ( $p<0.05)$, except for E. odorata and E. cinerea oils $(p>0.05)$.

The PCA horizontal axis explained $73 \%$ of the total variance, while the vertical axis a further $14.15 \%$ (Figure 5). The HCA indicated three groups of species (A, B and C) with a dissimilarity $\geq 5.0$ (Figure 6).

Group A, limited to Scopulariopsis brevicaulis, correlated negatively with axis 1 and with the group $C$. This species was distinguishable in the PCA and formed a distinct group. It was considered as being the most resistant to all the tested oils. Group B was formed by Trichophyton soudanense (correlating positively and negatively with axis 1 and 2, respectively) and by Trichophyton rubrum (correlating negatively with the two axes). These strains were distinguished by their highest sensitivity to E. odorata oil (100\% of inhibition); however, the variability between these two fungi strains was mainly due to the higher sensitivity of Trichophyton soudanense to E. lehmannii and E. maidenii oils than that of Trichophyton rubrum and also to the resistance of Trichophyton soudanense to E. cinerea oil. Group C, which was formed by the yeast Candida albicans and by the fungi Microsporum canis, correlated positively with the two axes and was characterized by a relatively high sensitivity to $E$. bicostata, E. astringens and E. sideroxylon; however, these strains showed a higher resistance to the other oils.

According to the chemical composition of these essential oils, the antifungal activity was not related to the high content of one chemical compound, rather than to synergic effects between major and minor components. For example, 1,8-cineole, which was discussed above as the principal component of the most essential oils, did

Table 3 Minimal Inhibition concentration (MIC), minimal bactericidal concentration (MBC) and ratio $\mathrm{MBC} / \mathrm{MIC}$ of the most effective oils against respiratory microorganisms

\begin{tabular}{|c|c|c|c|c|c|}
\hline \multirow[t]{2}{*}{ Essential oils } & \multicolumn{5}{|c|}{ Tested microorganisms } \\
\hline & & H.inf160 a) & Stre $B 3$ & S.pyo545 & S.aur278 \\
\hline \multirow[t]{3}{*}{ E. odorata } & MIC & $0.306^{b)}$ & 10.417 & 9.792 & 156.667 \\
\hline & $\mathrm{MBC}$ & 0.306 & 20.834 & 19.584 & 156.667 \\
\hline & $\mathrm{MBC} / \mathrm{MIC}$ & 1 & 2 & 2 & 1 \\
\hline \multirow[t]{3}{*}{ E. bicostata } & MIC & 0.331 & 10.562 & NT & 169.000 \\
\hline & $\mathrm{MBC}$ & 0.331 & 21.125 & NT & 169.000 \\
\hline & $\mathrm{MBC} / \mathrm{MIC}$ & 1 & 2 & NT & 1 \\
\hline \multirow[t]{3}{*}{ E. maidenii } & MIC & NT & NT & NT & 151.867 \\
\hline & $M B C$ & NT & NT & NT & 151.867 \\
\hline & $\mathrm{MBC} / \mathrm{MIC}$ & NT & NT & NT & 1 \\
\hline
\end{tabular}

a): H. inf 160= Hemophylus influenza (160); Strep B3 = Streptococus B3 = Streptococcus agalactiae3; S.pyo545= Streptoccus pyogenes; S.aur278= Staphylococcus aureus.

b): values were expressed as $\mathrm{mg} / \mathrm{ml}$; NT = Not tested. 
Table 4 Antifungal activity of seven Eucalyptus essential oils*)

\begin{tabular}{|c|c|c|c|c|c|}
\hline \multirow[t]{2}{*}{ Essential oils } & \multicolumn{5}{|c|}{ Tested microrganisms } \\
\hline & Trichophyton rubrum & Trichophyton soudanense & Microsporum canis & Scopulariopsis brevicaulis & Candida albicans \\
\hline E. maidenii & $31.9 \pm 2.1^{\mathrm{a} \cdot)}$ & $66.8 \pm 17.1^{b}$ & $53.9 \pm 0.0^{\mathrm{b}}$ & $22.8 \pm 2.1^{\mathrm{a}}$ & $60.0 \pm 0.0^{b}$ \\
\hline E. odorata & $100.0 \pm 0.0^{b}$ & $100.0 \pm 0.0^{b}$ & $100.0 \pm 0.0^{e}$ & $69.7 \pm 0.0^{\mathrm{a}}$ & $100.0 \pm 0.0^{b}$ \\
\hline E. sideroxylon & $30.4 \pm 0.0^{b c}$ & $29.0 \pm 6.4^{b}$ & $68.1 \pm 5.1^{d}$ & $12.2 \pm 4.3^{\mathrm{a}}$ & $40.0 \pm 0.0^{c}$ \\
\hline E. bicostata & $28.9 \pm 2.1^{\mathrm{a}}$ & $23.0 \pm 6.4^{\mathrm{a}}$ & $59.2 \pm 2.5^{\mathrm{b}}$ & $28.9 \pm 2.1^{\mathrm{a}}$ & $80.0 \pm 0.0^{c}$ \\
\hline E. astringence & $37.9 \pm 2.1^{b}$ & $38.1 \pm 2.1^{b}$ & $61.0 \pm 0.0^{c}$ & $22.8 \pm 10.7^{\mathrm{a}}$ & $60.0 \pm 0.0^{c}$ \\
\hline E. lehmannii & $27.3 \pm 0.0^{\mathrm{b}}$ & $39.6 \pm 4.3^{c}$ & $34.3 \pm 2.5^{c}$ & $0.1 \pm 0.0^{a}$ & $40.0 \pm 0.0^{c}$ \\
\hline E. cinerea & $24.3 \pm 0.0^{\mathrm{ab}}$ & $41.1 \pm 15.0^{c d}$ & $55.6 \pm 12.6^{d}$ & $4.6 \pm 6.4^{\mathrm{a}}$ & $40.0 \pm 0.0^{c d}$ \\
\hline Pevaryl (std) & $100.0 \pm 0.0^{\mathrm{a}}$ & $100.0 \pm 0.0^{\mathrm{a}}$ & $100.0 \pm 0.0^{\mathrm{a}}$ & $100.0 \pm 0.0^{\mathrm{a}}$ & $100.0 \pm 0.0^{\mathrm{a}}$ \\
\hline
\end{tabular}

${ }^{*}$ Values were expressed as a percentage of inhibition \pm SD at the concentration $1000 \mathrm{ppm}$ of triplicate determination.

-) Values with different letters differ significantly by Duncan's multiple range test $(p<0.05)$ std: standard for antifungal activity. E.: Eucalyptus.

not correlate with the high antifungal activity because $E$. cinerea (70.4 $\pm 2.5 \%)$, E. leucoxylon (59.2 $\pm 10.1 \%)$, E. lehmanii (56.6 $\pm 4.3 \%)$, and E. maidenii (57.8 $\pm 1.9 \%)$ showed a lower antifungal activity than E. bicostata, E. astringens and E. sideroxylon. Additionally, the essential oils of $E$. bicostata, E. astringens, characterized by the highest content of pinocarvone $(2.2 \pm 0.5$ and $1.8 \pm 0.8 \%$, respectively), tr-pinocarveol (4.6 \pm 0.6 and $7.0 \pm 2.5 \%$, respectively) and globulol (5.4 \pm 1.2 and $6.2 \pm 0.9 \%$, respectively), showed a lesser antifungal activity than the essential oil of E. sideroxylon.

\section{Cytotoxicity assay}

The cytotoxicity effect of the eight Eucalyptus essential oils on Vero cell lines varied significantly within species (Table 5). Vero cells were resistant to the essential oils of E. maidenii, E. sideroxylon and E. cinerea with $\mathrm{CC}_{50}$ values of 253.5, 247.3 and $204.5 \mathrm{mg} / \mathrm{mL}$, respectively. The essential oils of E. odorata, E. leucoxylon, E. lehmannii, E. astringens and E. bicostata demonstrated a different behavior and their cytotoxicity increased considerably with $\mathrm{CC}_{50}$ varying from 6.2 to $16 \mathrm{mg} / \mathrm{mL}$. We did not notice any clear correlation between the

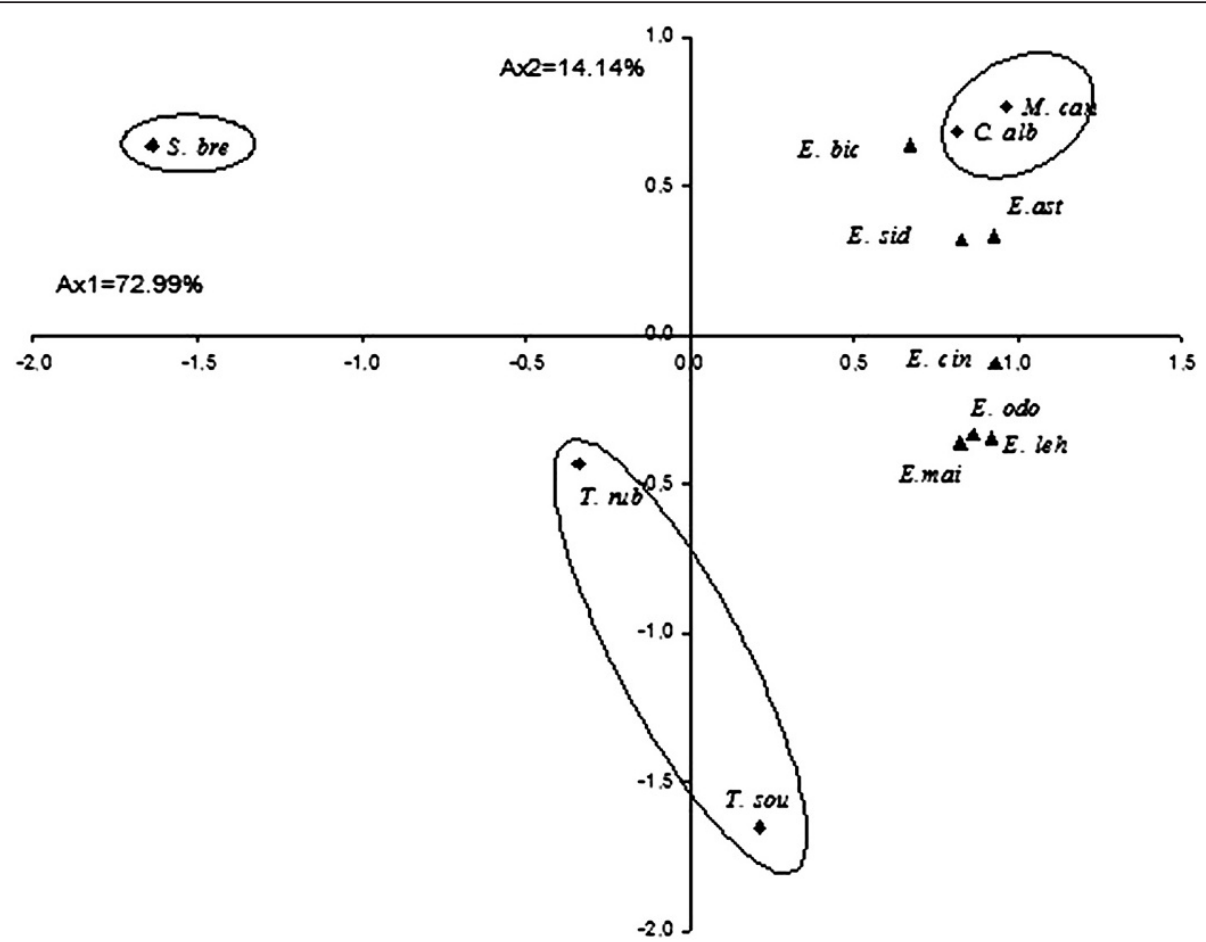

Figure 5 PCA of the antifungal activity of 08 Eucalyptus essential oils species against five fungi ( $\downarrow): T$. rub $=$ Trichophyton rubrum, $T$. sou = Trichophyton soudanense, $M$. can = Microsporum canis; S. bre $=$ Scopulariopsis brevicaulis, C. alb $=$ Candida albicans. For the abbreviation of the Eucalyptus species ( $\mathbf{\Lambda}$ ) (see Table 1). 


\section{Linkage Distance}

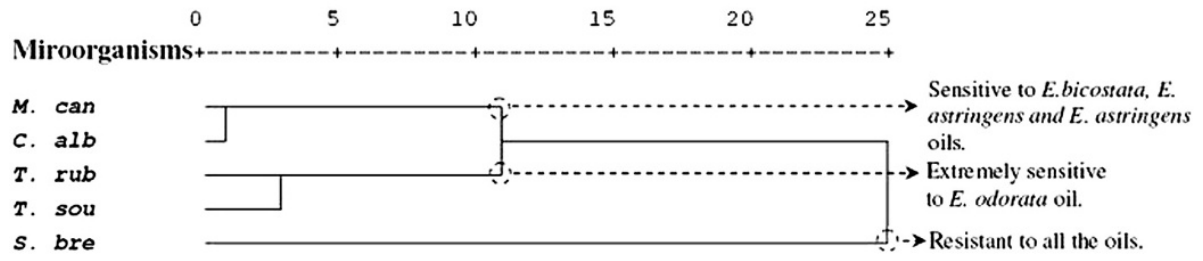

Figure 6 Dendrogram obtained by hierarchical cluster analysis based on the Euclidean distance between groups of the antifungal activities of leaf essential oils of seven Tunisian Eucalyptus species. For the abbreviation of the fungi strains, see Figure 5.

chemical composition of the tested oils with the results of the cytotoxic effect and further investigation needs to be undertaken. However, the lowest cytotoxicity was observed with oils having a high content of 1,8-cineole but with a moderate amount of $\alpha$-pinene and limonene such as those of E. maidenii, E. sideroxylon and E. cinerea. The high cytotoxic effect was shown with $E$. lehmannii, $E$. astringens oils, which were characterized by a higher mean percentage of the monoterpene $\alpha$-pinene and by a moderate mean percentage of 1,8-cineole. The present result was confirmed by Setzer et al. (2006) [39], who demonstrated that the monoterpene hydrocarbons $\alpha$-pinene had a stronger cytotoxicity activity against $\mathrm{Hs} 578 \mathrm{~T}$ and HepG2 cell lines than 1,8-cineole. It was also observed that a

Table 5 Cytotoxicity effect and antiviral activity of eight Eucalyptus essential oils

\begin{tabular}{|c|c|c|c|c|c|c|c|c|}
\hline \multirow{2}{*}{$\begin{array}{l}\text { Essential } \\
\text { oils }\end{array}$} & \multirow[t]{2}{*}{$\mathrm{CC}_{50}^{*}(\mathrm{mg} / \mathrm{mL}, \pm \mathrm{SD})$} & \multirow{2}{*}{$\begin{array}{l}\text { Concentrations } \\
(\mathrm{mg} / \mathrm{mL})\end{array}$} & \multicolumn{6}{|c|}{ Antiviral activity } \\
\hline & & & Pre-treatment of cells & $\mathrm{IC}_{50}(\mathrm{mg} / \mathrm{ml})$ & SI & Pre-treatment of virus & $I C_{50}(\mathrm{mg} / \mathrm{ml})$ & SI \\
\hline \multirow[t]{3}{*}{ E. cin } & $204.5 \pm 0.35^{\mathrm{b} \cdot)}$ & 150 & 66.5 & $131^{\mathrm{b}}$ & $1.56^{\mathrm{a}}$ & 71 & $102^{\complement}$ & $2^{\mathrm{a}}$ \\
\hline & & 75 & 0 & & & 54 & & \\
\hline & & 37.5 & 0 & & & 0 & & \\
\hline \multirow[t]{3}{*}{ E. sid } & $247.3 \pm 0.9^{c}$ & 150 & 0 & $\mathrm{Nd}$ & $\mathrm{Nd}$ & 0 & $\mathrm{Nd}$ & $\mathrm{Nd}$ \\
\hline & & 75 & 0 & & & 0 & & \\
\hline & & 37.5 & 0 & & & 0 & & \\
\hline \multirow[t]{3}{*}{ E. mai } & $253.5 \pm 0.35^{c}$ & 150 & 29 & $233.5^{c}$ & $1.08^{\mathrm{a}}$ & 62.5 & $136.5^{d}$ & $1.85^{\mathrm{a}}$ \\
\hline & & 75 & 0 & & & 0 & & \\
\hline & & 37.5 & 0 & & & 0 & & \\
\hline \multirow[t]{3}{*}{ E. leh } & $15 \pm 00.0^{a}$ & 15 & 0 & $\mathrm{Nd}$ & $\mathrm{Nd}$ & 0 & $\mathrm{Nd}$ & $\mathrm{Nd}$ \\
\hline & & 7.5 & 0 & & & 0 & & \\
\hline & & 3.75 & 0 & & & 0 & & \\
\hline \multirow[t]{3}{*}{ E. bic } & $16 \pm 00.0^{\mathrm{a}}$ & 15 & 0 & $4.8^{\mathrm{a}}$ & $3.33^{b}$ & 0 & $0.7^{\mathrm{a}}$ & $22.8^{\mathrm{b}}$ \\
\hline & & 7.5 & 66.5 & & & 87.5 & & \\
\hline & & 3.75 & 37.5 & & & 83 & & \\
\hline \multirow[t]{3}{*}{ E. ast } & $15.7 \pm 0.14^{\mathrm{a}}$ & 15 & 0 & $\mathrm{Nd}$ & $\mathrm{Nd}$ & 83 & $8.4^{b}$ & $1.86^{\mathrm{a}}$ \\
\hline & & 7.5 & 0 & & & 46 & & \\
\hline & & 3.75 & 0 & & & 25 & & \\
\hline \multirow[t]{3}{*}{ E. leu } & $14.9 \pm 0.07^{a}$ & 15 & 0 & $\mathrm{Nd}$ & $\mathrm{Nd}$ & 0 & $\mathrm{Nd}$ & $\mathrm{Nd}$ \\
\hline & & 7.5 & 0 & & & 0 & & \\
\hline & & 3.75 & 0 & & & 0 & & \\
\hline \multirow[t]{3}{*}{ E. odo } & $6.2 \pm 0.14^{a}$ & 6 & 0 & $\mathrm{Nd}$ & $\mathrm{Nd}$ & 0 & $\mathrm{Nd}$ & $\mathrm{Nd}$ \\
\hline & & 3 & 0 & & & 0 & & \\
\hline & & 1.5 & 0 & & & 0 & & \\
\hline
\end{tabular}

${ }^{*}$ Values were expressed as a cytotoxic concentration \pm SD of duplicate determination.

-) Values with different letters differ significantly by Duncan's multiple range test $(p<0.05)$.

$\mathrm{Nd}$ : Not determined. 
synergic effect among the oxygenated sesquiterpens globulol and viridiflorol and the monterpene hydrocarbons $\alpha$-pinene of $E$. astringens, E. lehmannii and $E$. leucoxylon oils could make the cell lines more sensitive. On the other hand, the significant high cytotoxicity of $E$. odorata oil could be explained by the latter's lack of 1,8-cineole and its richness in the ketone cryptone, the monoterpene hydrocarbons $p$-cymene and in theses aldehydes: phellandral and cuminal [40]. This cytotoxicity effect could be due to the synergetic effect of the previous main constituents of this essential oil. Compared to the previous studies, the cytotoxicity of our studied essential oils was very low $\mathrm{CC}_{50}>20 \mu \mathrm{g} / \mathrm{mL}$ [21]. Therefore they could be considered as being safe for use at non cytotoxic concentrations.

\section{Antiviral activity}

In order to elucidate the mode of antiviral action and to identify the target site, cells were pre-treated with essential oils before viral infection (pre-treatment of cells) and the virus was incubated with essential oils before cell inoculation (pre-treatment of virus). All samples tested were used at their maximum non-cytotoxic concentrations (Table 5). The essential oils of E. sideroxylon, $E$. lehmannii, E. leucoxylon and E. odorata showed no inhibition of viral infection, whereas the most significant antiviral activity was shown with the essential oils of $E$. bicostata $\left(\mathrm{IC}_{50}=0.7-4.8 \mathrm{mg} / \mathrm{mL}\right)$ and $E$. astringens $\left(\mathrm{IC}_{50}=8.4 \mathrm{mg} / \mathrm{mL}\right)$, followed by essential oils of $E$. cinerea $\left(\mathrm{IC}_{50}=102-131 \mathrm{mg} / \mathrm{ml}\right)$ and $E$. maidennii $\left(\mathrm{IC}_{50}=\right.$ 136.5 - $233.5 \mathrm{mg} / \mathrm{mL}$ ). The selectivity index describes the ratio between the cytotoxic and the antiviral activity of a tested sample. The virus pretreatment with E. bicostata essential oil showed a better antiviral activity $\left(\mathrm{IC}_{50}=0.7 \mathrm{mg} / \mathrm{mL}, \quad \mathrm{SI}=22.8\right) \quad$ than cell-pretreatment $\left(\mathrm{IC}_{50}=4.8 \mathrm{mg} / \mathrm{mL}, \mathrm{SI}=3.33\right)$. The essential oil of $E$. astringens showed an antiviral activity only when incubated with a virus prior to cell infection. This activity was dose-dependent and the antiviral activity decreased with the diminishing essential oil concentration. $E$. cinerea and E. maidenii essential oils showed an antiviral activity at a concentration of $150 \mathrm{mg} / \mathrm{mL}$ when incubated with cells. This activity increased significantly at the same concentration when the sample was incubated with a virus prior to infection.

According to these results, no correlation was found between the chemical composition and the antiviral assay. Therefore the activity of the tested essential oils could be due to a synergism between the major and the minor components. Altogether, the essential oils used in the present study exhibited the best antiviral effect when incubated with a virus. From the presented results, E. odorata oil was associated with $E$. maidenii, E. bicostata, E. lehamnnii, E. astringens and
E. leucoxylon oils in both the antibacterial PCA and HCA. However, it remained associated with E. maidenii and E. lehmannii in the antifungal PCA analysis. Therefore, the biological activity has allowed the association of different chemotypes in the same group producing a similar biological activity. This allowed us to deduce that the global biological activity of these oils was mainly due to an addition or a synergism effect between the major and the minor components. This was confirmed by Paster et al. (1995) [41]. The best activity was recorded with $E$. odorata oil against the majority of the microbial strains with inhibition zone diameters almost equal to those produced by erythromycin against clinical strains $H$. inflenzae, $S$. aureus, and to the Pevaryl against the three dermatophytes fungi and the Candida albicans. This property could be explained by the richness of $E$. odorata oil in $p$-cymene $(16.7 \pm 5.2 \%), \quad$ terpinene- 4 -ol $\quad(3.0 \pm 0.8 \%)$, spathulenol $(3.2 \pm 0.9 \%)$, carvacrol $(1.7 \pm 0.3 \%)$, caryophyllene oxide $(1.7 \pm 0.2 \%), p$-cymene- 8 -ol $(2.9 \pm 0.6 \%)$, verbenone $(0.9 \pm 0.2 \%)$, viridiflorol $(1.0 \pm 0.3 \%)$, phellandral $(6.6 \pm 0.4 \%)$, cuminal $(6.6 \pm 0.6 \%)$ and cryptone $(20.9 \pm$ $1.3 \%)$, and by its poverty in 1,8 -cineole $(4.5 \pm 1.6 \%)$. It appeared that all the strains were resistant to oils rich in the latter component which varied from $42.0 \pm 5.9 \%$ for $E$. astringens to $70.4 \pm 2.5 \%$ for $E$. cinerea. On the other hand, oils characterized by a small quantity of 1,8-cineole and by a medium mean percentage of the monoterpene, $p$-cymene, the ketone, cryptone, the aldehydes, phellandral and cuminal were more active. These results were confirmed by Mulyaningsih et al. (2010) [42], who demonstrated that the antimicrobial activity of pure 1,8-cineole was inferior to the totality of E. globulus fruit oil, considered poor in the latter component and rich in aromadendrene and globulol. Dorman and Deans (2000), also confirmed that the antimicrobial activity increased with oils rich in aldehydes, ketones and phenols [43]. E. maidenii oil was characterized by a relatively high mean percentage of 1,8-cineole (57.8 $\pm 1.9 \%), p$-cymene $(7.4 \pm 2.9 \%), \alpha$-pinene $(7.3 \pm 0.7 \%)$, limonene (3.1 $\pm 0.2 \%), \alpha$-terpineol $(2.2 \pm 0.2 \%)$, the activity of which occupied the second position after $E$. odorata oil against all the bacterial strains $(7.1 \pm 1.5 \mathrm{~mm}$, zdi, for $P$. aeruginosa to $22.8 \pm 6.8 \mathrm{~mm}$, zdi, for $S$. aureus) and also against the fungal strains with an inhibition percentage varying from $22.8 \pm 2.1 \%$ for Scopulariopsis brevicaulis to $66.8 \pm 17.1 \%$ for Trichophyton soudanense. However, oils of E. sideroxylon and E. cinerea, which were distinguished by the highest levels in 1,8-cineole, were less active against the tested microorganisms than the majority of the remaining oils. The present finding was in contradiction with previous studies reporting that 1,8-cineole had strong antimicrobial properties against many important pathogens $[44,45]$. It seems that the activity of this chemical compound was inhibited by other minor components. 
Further investigations need to be carried out to better understand the present issue.

According to the study of Claudio et al. (2008), the essential oil of E. globulus has shown a higher antibacterial activity against Haemophilus influenzae (28 mm, zdi) than the tested essential oils in the present study, whereas it possessed comparative inhibition activities against $S$. pneumoniae (15 mm vs 9.8-17.4 mm, zdi). However, our essential oils exhibited a better activity against $K$. pneumoniae $(6.6-10.7 \mathrm{~mm}$ vs $0 \mathrm{~mm}$, zdi), $S$. aureus (12.2-27.4 mm vs $2 \mathrm{~mm}$, zdi), S. agalactiae (11.1$19.4 \mathrm{~mm}$ vs $3 \mathrm{~mm}$, zdi) and S. pyogenes (9-19 $\mathrm{mm}$ vs $5 \mathrm{~mm}, \mathrm{zdi}$ ) [46]. Martin et al. (2010) have reported similar findings concerning the antibacterial activity of the essential oils of $E$. dives and $E$. staigeriana against Pseudomonas aeruginosa (7.7-9.1 mm vs 6-7.1 mm, zdi) [47].

We also noticed that Microsporum canis is more sensitive to E. sideroxylon oil than that of E. cinerea. This sensitivity could be attributed to the presence of a higher content of $\alpha$-pinene and limonene and a lower percentage of $\alpha$-terpineol in E. sideroxylon oil. The comparative study of the antibacterial activity result of the tested oils obtained by the disc diffusion method with the results obtained by micro-well dilution showed for some species a concordance of the two methods and discordance for others, especially against the Gram positive (Gram (+)), S. aureus (278). Compared to the activities produced by the tested antibiotics, all the essential oils were less active. An association of the most active oils together may moderate the activity against the most resistant strains.

\section{Conclusions}

In conclusion, our study showed that the chemical PCA and HCA analysis separated all the species oils into three groups, each group constituted a chemotype; however, in the PCA and HCA analysis of the antibacterial activity, five groups and sub groups of bacterial strains were identified and separated by their sensitivity levels to the tested essential oils. E. cinerea of the group B was the richest species in 1,8-cineol. However, E. odorata oil of the group A was the richest in cryptone. The Eucalyptus essential oils activity varied significantly within species and within strains. In general, the strong antimicrobial activity was not related only to a high content of one major component such as 1,8-cineole, but also to the presence of moderate and minor compounds. The Gram (-) bacteria P. aeruginosa and K. pneumoniae were the most resistant to all the oils but more sensitive to the antibiotics, ciprofloxacin and ampicillin. Compared to antibiotics and antifungal fosfomycin, ampicillin, rifamycin and pevaryl, the clinical strains $S$. aureus, H. influenzae, S. agalactiae, S. pyogenes, S.pneumoniae and all the tested fungal strains were more sensitive to
E. odorata oil. Taking into account all these results, E. odorata oil provide a promising product in the therapeutic application for the treatment of some respiratory bacterial infections and fungal diseases. The cytotoxicity of the tested oils on Vero cell lines varied significantly within species. E. odorata oil which was the richest species in the ketone cryptone, had the highest cytoxicity, whereas E. maidenii, E. sideroxylon and E. cinerea oils, which were characterized by the highest mean percentage of 1,8-cineole and by a moderate amount of $\alpha$-pinene, were less toxic. E. bicostata oil had the best antiviral activity against coxsakievirus B3 whenever incubated with the Vero cell lines or with the virus. This essential oil may serve as a potential candidate against enterovirus infections. Further analyses need to be undertaken to test this essential oil on other viruses belonging to the genus enterovirus. However, E. astringens oil exhibited a significant antiviral activity only when incubated with the virus. This shows that this essential oil had a direct effect on the coxsakievirus B3. We could not elucidate the mode of action of these essential oils and their interactions with both cells and the virus remains to be elucidated.

\begin{abstract}
Abbreviations
E: Eucalyptus; GC: Gaz Chromatography; GC/MS: Gaz Chromatography coupled to the Mass Spectroscopy; HP: Hewlett-Packard; FID: Flame Ionization Detector; MH: Mueller-Hinton; MIC: Minimal Inhibition Concentration; MBC: Minimum Bactericidal Concentration; MTT: 3-[4,5-dimethylthiazol-2-yl]-2,5-diphenyl tetrazolium bromide; DMSO: Dimethyl Sulfoxide; OD: Optical density; CC50: The 50\% cytotoxic concentration; IC50: The 50\% inhibition concentration; PCA: Principal Components Analysis; HCA: Hierarchical Clusters Analysis; SI: Selectivity index; Rl: Retention index; Gram(-): Gram negative; Gram(+): Gram positive.
\end{abstract}

\section{Competing interests}

The authors declare that they have no competing interests.

\section{Authors' contributions}

AE and ZR carried out the studies, acquired the data, performed the data analysis, and drafted the manuscript. NA performed the cytotoxic and the antiviral assays. YBS played a major role in the experimental procedures of the antibacterial activities. SM and KB MA helped in the experimental procedure of the antifungal activity. FF and R.C offered the material such as (GC apparatus and the Pharmacopoeia European hydrodistilator apparatus) and revised the manuscript. FHS carried out the statistical analysis, and involved in the interpretation of the results and in the final revision of the work. MLK offered us the vegetable material.All authors read and approved the final manuscript.

\section{Acknowledgements}

This research was supported by the "Ministère Tunisien de l'Enseignement Supérieur, de la Recherche Scientifique et de la Technologie" through the "Laboratoire de pharmacognosie" (Unité de recherche sur la Valorisation des Plantes Aromatiques et Médicinales), "Laboratoire de Microbiologie,

Immunologie, EPS Farhat Hachad de Sousse" (Tunisia) and "Laboratoire des Maladies Transmissibles et Substances biologiquement actives" (LR99ES27).

\section{Author details}

${ }^{1}$ Laboratory of Pharmacognosy, Faculty of Pharmacy, University of Monastir, Avenue Avicenne, Monastir 5019, Tunisia. ${ }^{2}$ Laboratory of Transmissible Diseases and Biologically Active Substances, Faculty of Pharmacy, University of Monastir, rue Avicenne, Monastir 5000, Tunisia. ${ }^{3}$ Laboratoire of Microbilogy, Imuunology, EPS Farhat Hachad, Sousse, Tunisia. ${ }^{4}$ Laboratory of 
Analytical Chemistry, Faculty of Pharmacy, University of Monastir, Avenue Avicenne, Monastir 5019, Tunisia. ${ }^{5}$ Laboratory of Genetic, Biodiversity and Bio-resources Valorisation, Higher Institute of Biotechnology of Monastir, University of Monastir, Avenue Tahar Haddad, Monastir 5000, Tunisia. ${ }^{6}$ National Institute for Research on Rural Engineering, Water and Forestry, Institution of Agricultural Research and Higher Education, Ariana, BP N.2, 2080, Tunisia.

Received: 22 March 2012 Accepted: 25 June 2012

Published: 28 June 2012

\section{References}

1. Brooker MI, Keing DA: Field guide to Eucalyptus (2nd ed.). In Bloomings Book. Northern Australia: Melbourne; 2004

2. Pino JA, Marbot R, Quert R, Garcia H: Study of essential oils of Eucalyptus resinifera Smith, E. tereticornis Smith and Corymbia maculata (Hook.) K. D. Hill \& L. A. S. Johnson, grown in Cuba. Flavour Fragr J 2002, 17:1-14.

3. Cermelli C, Fabio A, Fabio G, Quaglio P: Effect of eucalyptus essential oil on respiratory bacteria and viruses. Curr Microbiol 2008, 56:89-92.

4. Boukef MK: Médicine traditionnelle et pharmacopée, les plantes dans la médicine traditionnelle tunisienne. Agence de Coopération Culturelle et Technique 1986, 92:9028-085-9.

5. Fabio A, Cermelli C, Fabio G, Nicoletti P, Quaglio P: Screening of the antibacterial effects of a variety of essential oils on microorganisms responsible for respiratory infections. Phytother Res 2007, 21:374-377.

6. Sartorelli P, Marquioreto AD, Amaral-Baroli A, Lima ME, Moreno PR: Chemical composition and antimicrobial activity of the essential oils from two species of Eucalyptus. Phytother Res 2007, 21:231-233.

7. Tyagi AK, Malik A: Antimicrobial potential and chemical composition of Eucalyptus globulus oil in liquid and vapour phase against food spoilage microorganisms. Food Chem 2011, 126:228-235.

8. Ramezani H, Singh HP, Batish DR, Kohli RK: Antifungal activity of the volatile oil of Eucalyptus citriodora. Fitoterapia 2002, 73:261-262.

9. Rakotonirainy MS, Lavédrine B: Screening for antifungal activity of essential oils and related compounds to control the biocontamination in libraries and archives storage areas. Int Biodeterior Biodegrad 2005, 55:141-147.

10. Su YC, Ho CL, Wang El, Chang ST: Antifungal activities and chemical compositions of essential oils from leaves of four Eucalyptus. Taiwan $J$ For Sci 2006, 21:49-61.

11. Cermelli C, Fabio A, Fabio G, Quaglio P: Effect of Eucalyptus Essential oil on Respiratory Bacteria and Viruses. Curr Microbiol 2008, 56:89-92.

12. Schnitzler $P$, Schon $K$, Reichling J: Antiviral activity of Australian tea tree oil and eucalyptus oil against herpes simplex virus in cell culture. Pharmazie 2001, 56:343-347.

13. Elaissi A, Bel Haj Salah K, Mabrouk S, Chemli R, Harzallah-Skhiri F: Antibacterial activity and chemical composition of 20 Eucalyptus species essential oils. Food Chem 2011, 129:1427-1434.

14. Elaissi A, Rouis Z, Mabrouk S, Bel Haj Salah K, Mahjoub A, Khouja ML, Farhat F, Chemli R, Harzallah-Skhiri F: Correlation between chemical composition and antibacterial activity of essential oils from fifteen Eucalyptus species growing in the Korbous and Jbel Abderrahman Arboreta (North East Tunisia). Molecules 2012, 17:3044-3057.

15. Wiley Registry of Mass Spectral Data/NIST Spectral Data/CD Rom: Wiley Registry of Mass Spectral Data/NIST Spectral Data/CD Rom. 7th edition. York: John Wiley \& SonsNew; 1998

16. Şahin F, Güllüce MC, Daferera D, Sökmen M, Polissiou M: Biological activities of the essential oils and methanol extract of Origanum vulgare ssp. vulgare in the Eastern Anatolia region of Turkey. Food Control 2004, 15:549-557.

17. Lambert ZN: Antibiogramme: méthodes standard et automatique lecture interprétative. In Bases biologiques de l'antibiothérapie. Edited by BergogneBérézin E, Brogard JM. Paris: Masson; 1998.

18. Sovcíková A, Mikulásová M, Horáková K, Floch L: Antibacterial and mutagenic activities of new isothiocyanate derivatives. Folia Microbiol (Praha) 2001, 46:113-117.

19. Bel Haj Salah K, Mahjoub MA, Ammar S, Michel L, Millet-Clerc J, Chaumont JP, et al: Antimicrobial and antioxidant activities of the methanolic extracts of three Salvia species from Tunisia. Nat Prod Res 2006, 20:1110-1120
20. Singh G, Upadhyay RK, Narayanan CS, Padmkumari KP, Rao GP: Chemical and fungitoxic investigations on the essential oil of Citrus sinensis (L.) Pers. Deutshe Zeitschrift fuer Pflanzenkrankheiten und Pflanzenschutz 1993, 100:69-74.

21. Magadula JJ, Sulmimani HO: Cytotoxic and anti-HIV activities of some Tanzanian Garcinia species. Tanzan J Health Res 2010, 12:1-7.

22. Taleb C, Petit M, Pileni P: Synthesis of Highly Monodisperse Silver Nanoparticles from AOT Reverse Micelles: A Way to 2D and 3D SelfOrganization. Chem Mater 1997, 9:950-959.

23. Elaissi A, Marzouki H, Medini H, Khouja ML, Farhat F, Lyenne F, et al: Variation in volatile leaf oils of thirteen Eucalyptus species harvested from Souinet arboreta (Tunisia). Chem Biodivers 2010, 7:909-921.

24. Elaissi A, Medini H, Khouja ML, Monique S, Farhat F, Lyenne F, Chemli R, Harzallah-Skhir F: Variation in volatile leaf oils of eleven Eucalyptus species harvested from Korbous arboreta (Tunisia). Chem Biodivers 2010, 7:1841-1854.

25. Elaissi A, Medini $H$, Khouja ML, Simmonds M, Lynen F, Farhat F, et al: Variation in volatile leaf oils of five Eucalyptus species harvested from Jbel Abderrahman (Tunisia). Chem Biodivers 2011, 8:352-361.

26. Li H, Madden JL, Potts BM: Variation in volatile leaf oils of the Tasmanian Eucalyptus species II subgenus Symphyomyrtus. Biochem Syst Ecol 1996, 24:547-569.

27. Zrira S, Bessiere JM, Menut C, Elamrani A, Benjilali B: Chemical composition of the essential oil of nine Eucalyptus species growing in Morocco. Flav Fragr J 2004, 19:172-175

28. Dunlop PJ, Bignell CM, Hibbert DB, Brooker MIH: Use of gas chromatograms of the essential leaf oils of the genus Eucalyptus for taxonomic purposes: E. subser. Euglobulares (Blakely). Flav Fragr J 2003, 18:162-169.

29. Kiran Babu GD, Singh B: Simulation of Eucalyptus cinerea oil distillation: A study on optimization of 1,8 cineole production. Biochem Eng J 2009, 44:226-231.

30. Hmamouchi M, Bendali M, Zouhdi M, Agoumi A, Pelecuer J: Etudes chimiques et microbiologiques des huiles essentielles de quelques espèces d'Eucalyptus marocaines. Rev Med Pharm Afr 1992, 6:109-114.

31. Cimanga K, Kambu K, Tona L, Apers S, De Bruyne T, Hermans N, Totte J, Pieters L, Vlietinck AJ: Correlation between chemical composition and antibacterial activity of essential oils of some aromatic medicinal plants growing in the Democratic Republic of Congo. J Ethnopharmacol 2002, 79(2):213-220.

32. Bignell CM, Dunlop PJ, Brophy JJ, Jackson JF: Volatile Leaf Oils of some South-western and Southern Australian Species of the Genus Eucalyptus. Part XI. Subgenus Symphyomyrtus. A-Section Bisectaria. (a) Series Occidentales, (b) Unpublished series Annulatae, (c) Series Micromembranae, (d) Series Obliquae, (e) Series Dundasianae, (f) Series Cooperianae, (g) Series Halophilae, (h) Series Salmonophloiae, and (i) Series Pubescentes. B-Section Dumaria. (a) Series Merrickianae. Flav Fragr J 1996, 11:107-112.

33. Sefidkon F, Bahmanzadegan A, Assareh MH, Abravesh Z: Seasonal Variation in Volatile Oil of Eucalyptus Species in Iran. J. Herbs Spices Med. Plants 2009, 15:106-120.

34. Bignell CM, Dunlop PJ, Brophy JJ, Jackson JF: Volatile leaf oils of some South-western and Southern Australian species of the genus Eucalyptus part VI-subgenus symphyomyrtus, section adnataria. Flav Fragr $J 1995$, 10:359-364.

35. Bakkali F, Averbeck S, Averbeck D, Idaoma M: Biological effects of essential oils-A review. Food Chem Toxicol 2008, 46:446-475.

36. Essawi T, Sourour M: Screening of some Palestinian medicinal plants for antibacterial activity. J Ethnopharmacol 2000, 70:343-349.

37. Schaechter M, Medoff G, Barry I, Eisenstein BI: Microbiologie et pathologie infectieuse. Paris: De Boeck University; 1999.

38. Soro D, Kone MW, Kamanzi K: Evaluation des activités antimicrobiennes et anti-radicaux libres de quelques taxons bioactifs de Côte d'Ivoire. Eur J Sci Res 2010, 40:307-317.

39. Setzer WN, Schmidt JM, Noletto JA, Vogler B: Leaf oil compositions and bioactivities of Abaco bush medicines. Pharmacology Online 2006, 3:794-802.

40. Akolade JO, Olajide, Olutayo O, Afolayan MO, Akande SA, Idowu DI, et al: Chemical composition, antioxidant and cytotoxic effects of Eucalyptus globulus grown in north-central Nigeria. J Nat Prod Plant Resour 2012, 2:1-8. 
41. Paster N, Menasherow M, Ravid U, Juven B: Antifungal activity of oregano and thyme essential oils applied as fumigants against fungi attacking stored grain. J Food Protect. 1995, 58:81-85.

42. Mulyaningsih S, Sporer F, Zimmermann S, Reichling J, Wink M: Synergistic properties of the terpenoids aromadendrene and 1,8-cineole from the essential oil of Eucalyptus globulus against antibiotic-susceptible and antibiotic-resistant pathogens. Phytomedicine 2010, 17:1061-1066.

43. Dorman HJ, Deans SG: Antimicrobial agents from plants: antibacterial activity of plant volatile oils. J Appl Microbiol 2000, 88:308-316.

44. Bakkali F, Averbeck S, Averbeck D, Idaomar M: Biological effects of essential oils-A review. Food Chem Toxicol 2008, 46:446-475.

45. Rosato A, Vitali C, De Laurentis N, Armenise D, Milillo M: Antibacterial effect of some essential oils administered alone or in combination with Norfloxacin. Phytomedicine 2007, 14:727-732.

46. Cermelli C, Fabio A, Fabio G, Quaglio P: Effect of eucalyptus essential oil on respiratory bacteria and viruses. Curr Microbiol 2008, 56(1):89-92.

47. Gilles M, Zhao J, An M, Agboola S: Chemical composition and antimicrobial properties of essential oils of three Australian Eucalyptus species. Food Chem 2010, 119(2):731-737.

doi:10.1186/1472-6882-12-81

Cite this article as: Elaissi et al:: Chemical composition of 8 eucalyptus species' essential oils and the evaluation of their antibacterial, antifungal and antiviral activities. BMC Complementary and Alternative Medicine 2012 12:81.

\section{Submit your next manuscript to BioMed Central and take full advantage of:}

- Convenient online submission

- Thorough peer review

- No space constraints or color figure charges

- Immediate publication on acceptance

- Inclusion in PubMed, CAS, Scopus and Google Scholar

- Research which is freely available for redistribution 